\title{
BEYOND METAPHOR: AN ANALYSIS OF FIDUCIARY OBLIGATION
}

\author{
Deborah A. DeMotT*
}

Fiduciary obligation is one of the most elusive concepts in AngloAmerican law. Applicable in a variety of contexts, and apparently developed through a jurisprudence of analogy rather than principle, the fiduciary constraint on a party's discretion to pursue self-interest resists tidy categorization. Although one can identify common core principles of fiduciary obligation, these principles apply with greater or lesser force in different contexts involving different types of parties and relationships. Recognition that the law of fiduciary obligation is situation-specific should be the starting point for any further analysis.

Because of the wide range of situations in which the obligation may arise, the law of fiduciary obligation has developed through analogy to contexts in which the obligation conventionally apphes. Judicial opinions in this well-established tradition first identify paradigni cases in which fiduciary obligation applies and then examine whetler the relationship involved in the litigation is sufficiently like tlose in the paradigni cases to support an extension of the obhgation to that relationship. ${ }^{1}$ Courts also resort to analogy in order to determine the rules applicable to a fiduciary in a particular situation. ${ }^{2}$ Additionally, if an agreement defines the parties' relationship to any extent, the court must consider the impact of the agreement's terins on the apphicable fiduciary norms. The difficulty of this task sliould not be underestimated.

In atteinpting to define the parameters of fiduciary obligation in the corporate context, courts and cominentators have soinetimes drawn on contract-law principles as one particular mode of analogy. While contract-law principles may be helpful in illuminating some of the distinctive cliaracteristics of fiduciary obligation, when these principles are applied analytically to resolve questions of fiduciary obligation, they inevitably make only a limited contribution. Resorting unreflectively to contract rhetoric is insidiously misleading and provides no rationale for further

\footnotetext{
* Professor of Law, Duke University. I am grateful to my colleagues Stanley Fish and John Weistart for their comments on earher versions of this Article.

1. See, e.g., Meinhard v. Salmon, 249 N.Y. 458, 466-67, 164 N.E. 545, 547-48 (1928) (coadventurers' duties analogous to those of partners).

2. See, e.g., In re Estate of Swiecicki, 106 Ill. 2d 111, 117-18, 477 N.E.2d 488, 490 (1985) (relation of guardian and ward analogous to that of trustee and beneficiary).
} 
development of the law of fiduciary obhigation. My thesis is that, even considering the obligation's elusive nature, descriptions drawn exclusively from contract principles are surely mistaken.

Indeed, one of the descriptions of fiduciary obligation criticized in this Article reflects a mistaken metaphorical use of technical legal terms-a mistaken equation of fiduciary obligation with aspects of contract law. ${ }^{3}$ A review of the general principles of fiduciary obligation prefaces the demonstration that this equation is erroneous. The Article then examines the features of contract law that seem closest in function to the fiduciary obligation. It next reviews theoretical attempts to state a general justification for fiduciary obhigation or to provide a general explanation of the obligation, and concludes with an examination of a few current issues in corporate law to which these theoretical disputes are relevant.

\section{Fiduciary Obligation as Judicial Guess}

\section{A. Historical Background.}

The historical development of the law of fiduciary obligation is crucial to an understanding of its elusiveness. As a legal principle, the obhgation originated in Equity. Equity granted relief-and common law courts did not-in numerous situations involving one person's abuse of confidence reposed in him by another. ${ }^{4}$ As Equity evolved, concrete rules in many instances supplanted the chancellors' exercise of discretion based on broad principles; established usages for terns hike "trust" and "confidence" replaced an earlier and imprecise vocabulary. ${ }^{5}$ The term "fiduciary" itself was adopted to apply to situations falling sliort of "trusts," but in which one person was nonetheless obliged to act like a trustee. 6

Not surprisingly, the corporate forn of business organization proved to be fertile ground for application and development of fiduciary principles. A corporation's directors occupy a trustee-like position: unlike trustees, directors do not themselves have legal ownership interests in transferable property beneficially owned by others, but, like trustees,

3. A metaphor, as a figure of speech, treats two dissimilar things as identical in order to call attention to their similarities. L. LEMON, A GLOSSARY FOR THE STUDY OF ENGLISH 72 (1971). Using a technical legal term metaphorically is problematic when the connotations of the metaphorical use are at odds with the conclusions one would reach through analytic application of the relevant legal concept. For example, referring to a transaction as "fraudulent" when key elements of any relevant statutory or common law definition of "fraud" are missing is, in a technical context, a dubious metaphorical usage. See infra text accompanying notes 43-51.

4. Sealy, Fiduciary Relationships, 1962 CAMBRIDGE L.J. 69, 69-70.

5. Id. at $70-71$.

6. Id. at 71-72. 
directors are entrusted with powers to use in the interest of others. Invested by corporation statutes with discretionary authority to inanage or supervise the inanagement of the corporation's business, directors are bound by fiduciary principles.

The evolution of fiduciary obhgation thus owed much to the situation-specificity and flexibility that were Equity's hallmarks. Moreover, as Equity developed to correct and supplement the common law, ${ }^{7}$ the interstitial nature of Equity's doctrines and functions made these doctrines and functions resistant to precise definition. In the corporate context in the Uuited States, the continued evolution of fiduciary norns was shaped significantly by the institutional fact that the most prominent corporate law court-Delaware's Chancery Court-was (and still is) a separate court of equity, ${ }^{8}$ operating with a self-consciously equitable style. ${ }^{9}$ As a result of this history, the development of the adjective law ${ }^{10}$ of fidu-

7. Sé R. David, Major Legal Systems In the World Today 342 (3d ed. 1985).

8. Unlike most jnrisdictions in the United States, Delaware has never merged law and equity. See D. Lunt, Tales of the Delaware Bench and Bar 194 (1963). See generally F. James \& G. HAZARD, CIVIL PROCEDURE $\S 1.6$ (3d ed. 1985) (describing elinination of parallel court systems and merger of law and equity).

9. This proposition, widely accepted as true by Delaware practitioners, is amenable to less anecdotal support as well. The court is called the "Court of Chancery" and its judges the "Chancellor" and "Vice-Chancellors." The court has jurisdiction over traditionally "equitable" matters, such as trusts and guardianship proceedings, as well as all actions in which the plaimtiff seeks an equitable remedy. See DEL. CODE ANN. tit. 10, $\$ 341$ (1975). If the parties have sufficient remedies before any other court, Chancery "shall not have" jurisdiction to determine the matter. Id. $\S 342$.

That Chancery is a court of equity is also mamifest in its relationship with the Delaware Snprene Court. It is not unusual for the Supreme Court to pronulgate in opmions what appear to be firm rules of black letter law, but to couple these rules with express acknowledgments of Chancery's power to vary their application under the circumstances of a particular case. See, e.g., Aronson v. Lewis, 473 A.2d 805, 815 n.8 (Del. 1984) (acknowledging Chancery's discretionary review in determining excuse of demand requirement in shareholder derivative actions). As a result, although a rule itself niay not be explicitly discretionary, discretion in interpretation and enforcenent arises from the institutional fact that Chancery is a court of equity.

The perceived quality of Delaware's Chancery Court as a forum for corporate litigation provides a conventional justification for Delaware's attractiveness as a situs for incorporation. This fact might well cause one to qnestion the wisdom of abolishing courts of equity in other jurisdictions. Or at least one night wonder whether abolition results in losses as well as benefits.

10. That is, the rules of law and institutions that define how the substantive law is administered are, at least with respect to fiduciary obligation, crucial to understanding its intport as a substantive body of law. One scholarly conmentary on equity defines fiduciary obligation principally through its adjective aspect: "Broadly, it may be said that a fiduciary relationship exists, giving rise to obligations of that character, where the relationship is one of confidence, in which equity imposes duties upon the person in whom confidence is reposed in order to prevent the abuse of the confidence." $R$. Meagher, W. Gummow \& J. Lehane, Equity: Doctrines \& Remedies 123 (2d ed. 1984). See generally Davis, Judicial Review of Fiduciary Decisionmaking - Some Theoretical Perspectives, 80 NW. U.L. REv. 1 (1985) (explaining rules governing judicial review of fiduciary decisionnıaking as praginatic accomnodation of coinparative difficulties with legal regulation and private ordering).

That this body of law is judge-1nade would explain why commentators occasionally refer to it as a "common law" phenomenon. See, e.g., Clark, Agency Costs versus Fiduciary Duties, in PrincI- 
ciary obligation is inseparably a part of the obligation's substantive content.

\section{B. General Principles.}

Fiduciary obligation is not unique to corporate law. In general terms, the law governing fiduciary obligation addresses two questions: First, in what circumstances does fiduciary obligation apply? Second, what does the obligation require a person to do? If a person in a particular relationship with another is subject to a fiduciary obhigation, that person (the fiduciary) nuust be loyal to the interests of the other person (the beneficiary). The fiduciary's duties go beyond mere fairness and honesty; they oblige him to act to furtler the beneficiary's best interests. The fiduciary must avoid acts that put his interests im conflict with the beneficiary's. For example, if the fiduciary contracts with the beneficiary, the contract is voidable by the beneficiary unless the fiduciary has disclosed his interests adequately under the circumstances. ${ }^{11}$ If the fiduciary benefits through acts inconsistent with his obligation of fidelity, the beneficiary can recover any benefit realized by the fiduciary unless he consents to the fiduciary's retention of it. ${ }^{12}$ In transactions between the fiduciary and the beneficiary, therefore, the fiduciary nuust be candid and must evince utniost good faith. ${ }^{13}$

To be sure, the ranifications of these basic principles are coniplex, as inay be the determination whether, in a particular relationship, a fiduciary obligation exists in the first place. Only confusion will result if a court grounds its approach in a mistaken conception of fiduciary obligation. A recent Seventh Circuit case, Jordan v. Duff \& Phelps, Inc., ${ }^{14}$ provides a vivid illustration. Jordan addresses this relatively simple question: How candid must a fiduciary be in his dealings with a beneficiary? More narrowly stated, the issue in Jordan is whether a closely leeld corporation breaches its fiduciary obligation to an eniployee-sliareholder by neglecting to disclose, when it repurchases lis sliares, that negotiations that might lead to a merger between the corporation and another entity are underway.

Pals AND Agents: The Structure of Business 55, 76 (J. Pratt \& R. Zeckhauser eds. 1986) (fiduciary rules "created by judges in the common law tradition"). Few areas of the law are as distinctively equitable in character as fiduciary obligation, and few owe so little of their origin or subsequent development to the common law.

11. Sealy, Some Principles of Fiduciary Obligation, 1963 CAMBR1DGE L.J. 119, 125-26.

12. Id. at 128 .

13. See P. Finn, Fiduciary Obligations 4 (1977).

14. 815 F.2d 429 (7th Cir. 1987), cert. dismissed, 108 S. Ct. 1067 (1988). 


\section{The Jordan Definition of Fiduciary Obligation.}

The employee-shareholder in Jordan had no express employment contract with the company and was thus an einployee at will. Like all the company's employees, as a condition of purchasing his shares he signed an agreenent providing that, upon the termination of his employinent for any reason, he or his estate "shall sell" his shares to the corporation, which "shall buy ... all [s] hares of the [c]orporation then owned by" the einployee or his estate, at a price equal to the shares' book value "on the December 31 which coincides with, or immediately precedes, the date of termination." 15 The written agreenent did not address the einployer's - or for that matter the employee's ${ }^{16}$-obligation to share information with the other party at the point of termination. As it happened, the plaintiff's employinent ended because he wished, for family reasons, to move to anotlier city. The plaintiff agreed witl his employer to work for the remainder of the year, whicll enabled him to receive the stock's book value as of the end of that year. ${ }^{17}$

The majority opinion in Jordan characterizes the relationship between the einployee-shareholder and the employer-corporation as one that imposes a fiduciary obligation on the corporation to disclose material facts to shareholders when purchasing their shares. Even if the "fact" at issue were one that a public corporation could justifiably withhold froin its shareholders and the securities markets generally, ${ }^{18}$ a

15. Id. at 432 .

16. One significant type of information in this context is the employee's knowledge of circumstances, not known to the employer, that would constitute cause for termination even if the employee were not an employee at will. Suppose the employer does not ask the employee whether any such circumstances are known to him. After the employer discovers the existence of such circumstances, should the employer be entitled to recover any amounts it has paid to the employee in exchange for cancellation of the employee's contract rights?

In Bell v. Lever Bros., 1932 App. Cas. 161 (P.C.), the former employer sought restitution of amounts it paid under such circumstances, arguing that had it known at the time of termination that its two employees had breached their fiduciary duty, it would not have paid them $£ 50,000$ to discharge the unexpired terms of their contracts. Had Lever known the true state of affairs, it could have terminated the employees for cause, without cost. The House of Lords reversed the lower court's award of restitution, stating that the employer was not mistaken as to the "identity" of what it bargained for and that, whether or not the employees breached their contract of employment, the employer, having bargained for a release of its obligations under that contract, got exactly what it bargained for. Id. at 223-26. Interestingly, the leading U.S. authority on restitution treats the analysis in Bell as an obvious misapplication of mistake analysis and strongly suggests that the outcome in a U.S. court would be different. See 2 G. PALMER, THE LAW OF RESTITUTION $\$ 12.2$, at 541-43 (1978). If the subject matter of a contract is an intangible interest (as an employee's rights under an employment contract would surely be), U.S. courts ignore the "identity" test applied in Bell and grant restitution when the parties' agreement rests on mistaken basic assumptions. Id. at 542-43.

17. Jordan, 815 F.2d at 432 .

18. See id. at 431. In Basic Inc. v. Levinson, 108 S. Ct. 978 (1988), the Court held that an issuer's denial that merger negotiations were taking place, when the parties had not yet reached 
closely held corporation like the one in Jordan may not, consistently with the fiduciary constraint, repurchase its shares without disclosing all information that would be significant to a reasonable shareholder's deliberations. ${ }^{19}$ Even though the plaintiff was an einployee at will, and even though the prior agreement bound him to sell his sliares to the corporation upon termination of his employment, his decision to leave was his; moreover, in the majority's view, the plaintiff's relationship with his employer was so amicable that he could have timed his departure to follow rather than precede the merger. ${ }^{20}$

The notion that a corporation owes a fiduciary obligation to its own shareholders poses analytic challenges of heroic dimensions, which part IV of this Article addresses. ${ }^{21}$ The immediate focus, though, is on the more general problems raised by the Jordan majority's description of the nature of fiduciary obligation. The obligation is, according to the opinion, "a standby or off-the-rack guess about what parties would agree to if they dickered about the subject explicitly."22 The dissenting judge agrees with this characterization of the obligation ${ }^{23}$ and also with the proposition that a corporation owes its shareholders a fiduciary obligation. ${ }^{24}$ In his analysis, however, the employee's contractual obligation to sell the company his stock upon termination of employment, along with his merely "contingent" claiin to employment as an employee at will, together eliminate any obligation that the corporation might otherwise have had to disclose price-sensitive information to its departing employee. According to the dissent, treating the corporation as bound by a fiduciary obligation to disclose information to its selling shareholder is inconsistent with the corporation's ability, as employer, to trigger at any time an obligation in the shareholder to sell his shares to the corporation

agreement in principle on the price and structure of the transaction, could be an actionable misstatement of a material fact under SEC Rule 10b-5, 17 C.F.R. $\S 240.10 b-5$ (1988). Absent a duty to disclose, the issuer's silence would not be actionable because under Rule $10 \mathrm{~b}-5$, silence is not considered misleading. Basic Inc., $108 \mathrm{~S}$. Ct. at 987 n.17. For a thoughtful discussion of the complex issues surrounding the issuer's duty to disclose such information, see Gabaldon, The Disclosure of. Preliminary Merger Negotiations as an Imperfect Paradigm of Rule 10b-5 Analysis, 62 N.Y.U. L. REV. 1218 (1987); see also infra notes $178-89$ and accompanying text.

19. Jordan, 815 F.2d at 434.

20. Id. at 436 (employer permitted "employees to time their departures to obtain the maximum advantage from their stock"). As it happened, the merger fell through. Although Jordan's employer reached a definitive merger agreement with its merger partner, a bank holding company, the Board of Governors of the Federal Reserve approved the transaction subject to a condition so onerous that the parties abandoned the merger. Id. at 433 . Less than a year later, however, a trust acquired Duff \& Phelps, Jordan's employer. Id. at 441.

21. See infra notes $166-89$ and accompanying text.

22. 815 F.2d at 436 .

23. Id. at 446-47 (Posner, J., dissenting).

24. Id. at 445 . 
by terminating him as an employee. Indeed, Illinois law, which governed the parties' employment relationship, permits an employer to terminate an employee at will for any reason, or for no reason, unless the termination contravenes "a clearly mandated public policy."25 That two opinions, applying the same conception of fiduciary obligation, reach opposite conclusions on identical facts is a good reason to examme their initial premise.

The definition of fiduciary obligation articulated in the Jordan opinions appears to be literally unprecedented in prior Anglo-American caselaw. The opimions define fiduciary obligation as the court's guess about wliat the parties would have agreed to, had they bargained over the matter. To the extent that the Jordan opinions suggest that this definition is anything other than a novel departure from prior caselaw, the representation is not accurate.

A brief example may help illustrate the degree of estrangement between the definition of fiduciary obligation in the Jordan opimions and prior caselaw. Consider a case in which a court held that a franchisor owed a fiduciary obligation to its franchisee. ${ }^{26}$ In Arnott v. American Oil $C o$., for example, the court held that the franchisor was under such an obligation and breached it by terminating the franchise. ${ }^{27}$ The parties' contractual relationship was defined by a term lease that did not oblige tlie franchisor to renew and that contained provisions admittedly breached by the franchisee. ${ }^{28}$ If Arnott is correct in constraining, through a fiduciary obligation, the franchisor's discretion to terminate its franchisee, then the assunption that this obligation is what the parties would have agreed to had they bargained over the matter is not even remotely plausible.

\section{Contract-Law Analysis.}

The "hypothetical bargain" approach, although heretofore unknown in the law of fiduciary obligation, does call to mind aspects of contract law, and perhaps the Jordan opinions echo these resonances. Parties can demonstrate with their behavior that they intend to have a contractual relationship on particular terms, even if their spoken or written words do not elaborate all of those terms. ${ }^{29}$ For example, in certain

25. Id. at 449 (quoting Barr v. Kelso-Burnett Co., 106 Ill. 2d 520, 525, 478 N.E.2d 1354, 1356 (1985)).

26. See generally Brown, Franchising-A Fiduciary Relationship, 49 TEx. L. REV. 650 (1971) (arguing that fiduciary principles should apply in franchising relationships).

27. 609 F.2d 873, 882-84 (8th Cir. 1979), cert. denied, 446 U.S. 918 (1980).

28. Id. at $877-79$.

29. RESTATEMENT (SECOND) OF CONTRACTS $\$ \S 4,19$ (1981). 
circumstances a promise to pay for goods or services can be inferred from a party's conduct: if I telephone a merchant and order goods to be delivered to me, a promise to pay the merchant's current price can fairly be inferred from my conduct. ${ }^{30}$ Contracts resulting from such circumstances are described as contracts "implied in fact"; their terms, if made express, are those that the parties would surely articulate if they had occasion to do so. ${ }^{31}$

Contract law also recognizes and enforces imphed-in-fact conditions to agreements. As with express conditions, the fulfillment of imphied-infact conditions determines whether performance is due, unless nonfulfillment of the condition is excused..$^{32}$ The parties' manifest intention controls the implication of implied-in-fact conditions, ${ }^{33}$ as it does with implied-in-fact contracts.

The "hypothetical bargain" approach inay also assist a court in allocating the burden of contract risks not explicitly addressed by the parties' agreement, and particularly in determining whether occurrence of a particular risk should excuse nonperformance. ${ }^{34}$ Finally, if the transaction is a sale of goods, article 2 of the Uniform Commercial Code supplements the terms of the parties' express agreement with standardized "gap filler" terms, provided that the parties' conduct is sufficient to show an intention to make a contract and that the court has a "reasonably certain" basis on which to fashion a reinedy. ${ }^{35}$

30. Id. $\S 4$ comment a, illustration 1 .

31. E. FARNSWORTH, CoNTRACTs $\S 3.15$, at 142 n.2 (1982). In contrast, the term "quasicontract" conventionally applies only to claims for redress of unjust enrichment. Id. $\S 2.20$. It is important not to confuse quasi-contract with the distinctly different concept of implied-in-fact contract. $I d$. $\$ 3.14$, at $142 \mathrm{n} .2, \$ 2.20$, at 99 n.3. In many "quasi-contracts," the parties do not intend to have a contractual relationship. See $i d . \S 2.20$, at 99 n.3. The opinions in Jordan clearly do not address issues pertinent to quasi-contractual liability. But cf. Weiss \& White, Of Econometrics and Indeterminacy: A Study of Investors' Reactions to "Changcs" in Corporate Law, 75 CALIF. L. REv. 551, $594 \mathrm{n} .188$ (1987) (characterizing as "quasi-contractual" the hypothetical bargain view of corporate law).

32. See E. FARNSWORTH, supra note $31, \S 8.3$, at 544.

33. See id. $\$ 8.2$, at $539 \& \mathrm{n} .13$.

34. Taylor v. Caldwell, 122 Eng. Rep. 309 (1863), is the leading case in the academic canon of contract cases taking the hypothetical bargain approach to risk allocation. The defendant in Taylor agreed to license the plaintiff to use a particular inusic hall on specified dates for specified entertainment extravaganzas. The parties' written agreement contained no provision dcaling with the possibility that the unusic hall might be destroyed prior to the speeified dates without fault of either party, as it was. The licensee sued to recover the expenses it incurred in preparation for the concerts. The court held that the parties' contraet should be understood to include an implied condition excusing nonperformance after destruction of the music hall, "because from the nature of the contract it is apparent that the parties contracted on the basis of [the hall's] continued existence." Id. at 314. The court implied the condition because it fulfilled "the intention of those who entered into the contract. For in the course of affairs men in making such contracts in general would, if it were brought to their minds, say that there should be such a condition." Id. at 312.

35. U.C.C. § 2-204(1), (3) (1978). 
In any event, these contract law doctrines operate so differently from fiduciary obligation that to invoke them, even vaguely, in contexts like Jordan only confuses the analysis. For starters, these creatures of contract law are controlled by the parties' manifest intention; fiduciary obligation sometimes operates precisely im opposition to intention as manifest in express agreements. The terms of an express agreement are surely not irrelevant to the fiduciary obligation analysis, but once a court concludes that a particular relationship has a fiduciary character, the parties' manifest imtention does not control their obhigations to each other as dispositively as it does under a contract analysis.

The Jordan opinions appear oblivious to the basic poimt that a fiduciary obligation may operate independently of the legal consequences of the parties' express agreement, however comprehensive the agreement may be. Consider a partnership in which one of the partners, having fallen out with her fellow partners, wishes to dissolve the partnership. The Uniform Partnership Act, like the common law, enables that partner to dissolve the partnership at will, and at any time. ${ }^{36}$ The partnership agreement may itself contaim provisions dealing with dissolution. But even if the partner's dissolution at will does not breach the partnership agreement, all partners remain accountable to the partnership as fiduciaries and must account to it "for any benefit, and hold as trustee for it any profits derived by [individual partners] without the consent of the other partners from any transaction connected with the formation, conduct, or hquidation of the partnership or from any use by [individual partners] of its property." 37 In short, having the right to terminate a relationship does not establisli the absence of fiduciary constraints on transactions connected with the termination. From this perspective, the employer's ability in Jordan to terminate the plaintiff's employment and thereby oblige him to sell his shares to the corporation is irrelevant to the einployer's obhigation, as fiduciary, to disclose information to the selling shareholder.

Arnott again provides a contrast to Jordan. To the extent that parties' manifest intention can be inferred froin the express terms of their written agreement, the parties in Arnott apparently did not intend to limit the franchisor's discretion in determining whether to renew the franchise. Thus, either the fiduciary restraint on the franchisor's ability to terminate is inconsistent with the parties' intention to the extent that such intention can be inferred from the express terms of their agreement, or the Arnott analysis requires an overly attenuated definition of

36. UNIF. PARTNERShIP ACT § 31(2) (1969).

37. Id. $\S 21(1)$. 
intention. ${ }^{38}$

Another profound dissimilarity between contract and fiduciary analysis is the remedy available if the obhigation is breached. If fiduciary obligation were as the Jordan opinions characterize it, one would expect the outcomes and remedies in many different cases to change. When a party breaches an implied-in-fact contract (or an express contract for that matter), and is sued for money damages, the plaintiff's recovery should quantify the advantage lost as a result of the defendant's nonperformance. The general goal of contract damages, in short, is to compensate the plaintiff for loss of an expected advantage. ${ }^{39}$ The law of fiduciary obligation calculates damages from a very different perspective. That perspective dictates that the plaintiff is entitled to recover specific restitution of any benefit that the defendant obtamed through his breach or, if specific restitution is not feasible, money damages that quantify the defendant's benefit. 40 Even if the fiduciary's actions have not injured the beneficiary, and even if the beneficiary has in some sense gained as a result of the fiduciary's act, the fiduciary must account to the beneficiary for its profits. ${ }^{41}$ More aggressive remedies to restore the benefit, such as equitable tracing or accountimg and the imposition of a constructive trust, may also be available. ${ }^{42}$ The key technical deficiency of the Jordan definition of fiduciary obhigation is thus its failure to correspond in basic respects to the existing caselaw. Further, as apphed in the case itself, the Jordan definition of fiduciary obligation leads to obvious indeterminacy.

\section{E. Metaphorical Use of Technical Legal Terms.}

These deficiencies in Jordan's treatinent of fiduciary obligation illustrate, among other things, the difficulty inherent in inetaphorical uses of technical language. Contract law is a richly textured body of law whose constructs cannot simply be transported into other legal contexts. ${ }^{43}$ Even if one could accurately characterize as a "standardized contract" the body of statutory law governing corporate formation, thus treating

38. Along these lines, judges writing in the Commonwealth tradition stress the importance of ascertaining the "true construction" of the contract, so that fiduciary obligation superimposed upon the express and implied terms of the contract will not alter the operation the parties intended their agreement to have. See Hospital Prods. Ltd. v. United States Surgical Corp., 55 A.L.R. 417, 455 (Austl. 1984) (Mason, J.).

39. See E. FARNSWORTH, supra note $31, \S 12.8$, at 839 .

40. See G. PALMER, supra note 16 , $\$ 2.11$, at 141-42.

41. See, e.g., In re Estate of Swiecicki, 106 Ill. 2d 111, 119, 477 N.E.2d 488, 491 (1985) (minor entitled to investment profits that guardian bank acquired in violation of fiduciary relationship).

42. See G. PALMER, supra note $16, \S 2.11$, at 142-43.

43. See, e.g., In re Baby M, 109 N.J. 396, 434-44, 537 A.2d 1227, 1246-50 (1988) (surrogate parenting agreement). See generally The Baby $M$ Contract: Is it Enforceable?, N.J.L.J., Feb. 26, 1987 , at 1 . 
that formation under a particular statute as an approximation of "what the parties would have agreed to," 44 caselaw prior to Jordan does not support extending this characterization to the body of judge-made law defining fiduciary obligation. True, some academic commentators-always without resort to case support-so characterize it, 45 but they appear, at least in this respect, to be traveling hight as legal theorists. That is, if the claim being made is descriptive, it is mistaken. If, on the other hand, the claim is normative, its normative character should be expressly acknowledged. Although judicial imposition of fiduciary obligation may reduce the necessity for parties to draft detailed contract provisions regulating the fiduciary's permissible uses of discretion, ${ }^{46}$ that result obviously does not establisl that the fiduciary obligation is-or even resembles-an implied-in-fact contract. Thus, the rhetorical and ideological appeal of contract law slould be distinguisleed from its analytic aptness in various legal contexts.

Even divorced from the operation of contract-law doctrines, the "hypothetical bargain" view of fiduciary obligation does not lielp to explain the law. For one thing, how liypothetical is the bargain? If it is an approximation of something that particular parties would liave agreed to, the content of the bargain will, like actual bargains, reflect many factors,

44. See R. POSNER, ECONOMIC ANALYSIS OF LAW 369-72 (3d ed. 1986). One difficulty, as Posner's text acknowledges, is determining who counts as "a party" for purposes of reconstructing the hypothetical agreement. For example, it is not likely that all of a corporation's creditors would, if given the opportunity, assent to the shareholders' limited liability for corporate debts. Judge Posner mentions the case of the "involuntary" provider of credit, such as a victim of an accidental tort, as a point where "[t]he contract analogy breaks down." Id. at 372. Additionally, the historical development of corporate law in the United States suggests that the "standardized contract" characterization is inore metaphorical than descriptive; until the early 1800 s, private and municipal corporations were not substantially differentiated in legal treatment. See Coffee, No Exit?: Opting Out, the Contractual Theory of the Corporation, and the Special Case of Remedies, 53 BrookLyN L. REv. 919,939 \& n.42 (1988).

45. See, e.g., Easterbrook \& Fischel, Corporate Control Transactions, 91 YALE L.J. 698, 702 (1982); Fischel, The Corporate Governance Movement, 35 VAND. L. REv. 1259, 1264 (1982). Other commentators have correctly observed that this characterization of fiduciary duty cannot be sustained. See, e.g., Brudney, Corporate Governance, Agency Costs, and the Rhetoric of Contract, 85 CoLUM. L. REv. 1403, 1407 n.15 (1985) (characterizing as "fanciful" the treatment of fiduciary constraint as hypothetical result of parties' bargain); Clark, supra note 10, at 68 (observing that "implicit-contracts" approach is "frequently indeterminate and therefore manipulable"); Farrar, Ownership and Control of Listed Public Companies-Revising or Rejecting the Concept of Control, in Company Law in Change 61 (B. Pettet ed. 1987) ("substitution of the more naive concepts of contract and agency for the sophistication of the existing legal concepts of corporation and fiduciary" is inappropriate); Seligman, $A$ Sheep in Wolf's Clothing: The American Law Institute Principles of Corporate Governance Project, 55 GEo. WASH. L. REv. 325, 348 (1987) (nexus-of-contracts and agency-costs approaches better seen as "crude generalizations or metaphors than as theories normally einployed in legal analysis").

46. Anderson, Conflicts of Interest: Efficiency, Fairness and Corporate Structure, 25 UCLA L. REv. 738, 760 (1978). 
including the scarcity of the subject matter of the bargain, the parties' relative skills in negotiation, and their relative degrees of aversion to risks of varied sorts. In the absence of an actual bargain, one cannot know the import of each of these factors. On the other hand, if the "hypothetical bargain" represented by fiduciary obligation is truly hypothetical, and not an approximation of what particular parties would have agreed to, why characterize it as a "bargain" at all? In this respect, the metaphor of the hypothetical bargain is like the Wizard of Oz. Behind the curtain is less than appearances might suggest.

Metaphor, when effectively used, is a powerful rhetorical device because it engages the reader's attention and imagination in ways that more literal uses of language do not. Metaphors, by requiring collaboration between the author and the reader, are like eniginas, riddles, ${ }^{47}$ and even jokes. ${ }^{48}$ Metaphors coinpel the reader to notice similarities between superficially dissinilar things, usually by asserting that they are identical. Even metaphors that are literally true, like "no inan is an island," have this effect. But comnuunicating one's thoughts through metaphor is inevitably an indirect process, ${ }^{49}$ one that draws on the perspective of particular readers and requires an audience of readers who possess considerable information about the writer's beliefs and background. The "Inetaphorical truth" that a metaphor conveys, even if it is indeed true, thus tends to vary soinewhat with each individual reader.

These characteristics of metaphor suggest two basic points about its use in legal contexts. First, although in soine legal contexts the use of metaphorical language seems entirely appropriate, in others it seenis just as entirely peculiar. One would not, for example, be surprised by metaphorical and other figurative uses of language in an advocate's argument to a jury, but surely one would be startled by the use of a metaphor in a statute or an indictment. "All taxpayers should bleed equally," as a provision in a tax code, or "the defendant is a shark," as a count in an indictment, are statements that would appear inappropriate, perhaps disconcertingly so, in those contexts. Too much of the statements' meaning turns on individual readers' ennotive responses to "blood" and "sharks," in contexts where nore rather than less precision in ineaning is evidently

47. See Booth, Metaphor as Rhetoric: The Problem of Evaluation, in ON METAPHOR 47, 63 (S. Sacks ed. 1979).

48. See Cohen, Metaphor and the Cultivation of Intimacy, in ON METAPHOR, supra note 47, at 1,8 ,

49. Some literary critics treat even metaphors in poetry as suspect, but nonetheless essential. Along these lines, I.A. Richards wrote, "There are few metaphors whose effect, if carefully examined, can be traced to the logical relations involved. Metaphor is a semi-surreptitious method by which a greater variety of elements can be wrought into the fabric of the [poetic] experience." I.A. RICHARDS, PRINCIPLES OF LITERARY CRITICISM 240 (1924). 
desirable. Second, the metaphorical use of technical legal terms, like "contract" or "agency" or "fraudulent," has even less to commend it in legal contexts where the potential for confusion is so great. Even if we were persuaded by philosophical arguments that, at some level, all language is rooted in metaphorical origins, ultimately traceable to essential equations between verbal symbols and nonverbal phenomena, ${ }^{50}$ we should still be disinclined to excuse the inetaphoric use of technical terms in workaday contexts like law. As C.S. Lewis wrote, "That metaphors, misread as stateinents of fact, are the source of inonstrous errors, need hardly be pointed out." 51 The error in Jordan may be less than "inonstrous"-itself a metaphorical usage-but no less regrettable for that.

The Jordan approach to fiduciary obligation is idiosyncratic in other respects as well. One is the absence in the opimions of analogies to other illustrative situations. As noted above, ${ }^{52}$ given the specific issue in Jordan, partnership seeins an obvious source on which to draw. The evolution of the law of fiduciary obligation illustrates, perhaps more powerfully than most bodies of law, the power of analogy in legal argumentation. ${ }^{53}$ Courts considermg whether to impose a fiduciary constraint in a novel context rely heavily on comparisons to more conventional contexts in which the constraint does apply. ${ }^{54}$ Although soine commentators find this pattern intellectually unsatisfying, ${ }^{55}$ its pervasiveness and persistence suggest that it is an inevitable aspect of fiduciary analysis.

Judicial opimions applying the fiduciary constraint are also distinctive, among private law cases, in that they frequently and explicitly use the language of inoral obligation to justify their outcomes. ${ }^{56}$ In establish1962).

50. Lewis, Bluspels and Flalansferes, in The IMPORTANCE of LANGUAGe 36 (M. Black ed.

51. Id. at 39.

52. See supra notes 36-37 and accompanying text.

53. Cf. E. Levi, AN INTROduction to Legal REASONING 4 (1949) ("Reasoning by example in the law is a key to many things."); Balkin, Too Good To Be True: The Positive Economic Theory of Law (Book Review), 87 CoLUM. L. REv. 1447, 1487 (1987) (Conceptual structures, including legal structures, always evolve through makeshift borrowings from and analogies to existing structures: "We simply make do with what we have and analogize from it.").

54. See, e.g., Meinhard v. Salmon, 249 N.Y. 458, 462, 164 N.E. 545, 546 (1928) (analogizing relationship between coadventurers to relationship among partners).

55. See, e.g., J. Shepherd, LAW of Fiduciaries 5 (1981); Frankel, Fiduciary Law, 71 Cal.r. L. REV. 795, 805 (1983).

56. Probably the example best known to lawyers in the United States is Chief Judge Cardozo's assertion in Meinhard v. Salmon that, "A trustee is held to something stricter than the morals of the market place. Not honesty alone, but the punctilio of an honor the most sensitive, is then the standard of behavior." 249 N.Y. at 464, 164 N.E. at 546. Commentators, too, participate in this rhetorical tradition. For example, Professor Scott's article entitled The Fiduciary Principle begins by quoting the parable in Luke 16:1-8 of the steward accused of wasting his master's goods. Scott, The Fiduciary Principle, 37 CALIF. L. REv. 539, 539 (1949). 
ing that the imposition of fiduciary obligation in a particular situation conforms to moral intuition, courts may be responding to the situationspecific quality of the obligation. They may also be responding to the stringency of the standards for assessing a fiduciary's behavior, as well as to the high social value placed on trust. In short, this pattern of judicial justification, far from constituting mere "sermonizing,"57 unay tell us something important about the nature of fiduciary obligation itself. At a minimum, it tells us that courts do not conceive of their function as a judicial guess about what the parties would have agreed to!

\section{Fiduciary Obligation Contrasted with Contract LaW}

Although the "hypotletical bargain" conception of fiduciary obligation is gravely inistaken, some aspects of contract law do respond to circumstances that may accompany the imposition of fiduciary obligation. Exploring these apparent similarities enables a more precise specification of fiduciary obligation's contribution to legal analysis. Accordingly, this part of the Article contrasts fiduciary obligation with selected aspects of contract law with which it shares intriguing similarities. The part first exaunines the contractual obligation to act in good faitl. It then contrasts fiduciary obligation with those aspects of contract law that specifically address parties' vulnerability to problennatic transactions and other parties' misbehavior.

\section{A. The Obligation to Act in Good Faith.}

Like fiduciary obligation, the obligation to act in good faith arises in a variety of contexts. Both obligations operate to limit a party's permissible use of discretion or of a power or advantage obtained over another person. Both are also protean in their operation, ${ }^{58}$ resisting attempts to capture their ineanings in general definitions. ${ }^{59}$ Moreover, analysis of the respective rights and duties created by these obligations is often complicated by the presence of an express agreement.

57. Clark, supra note 10, at 76; cf. Hetherington, Defining the Scope of Controlling Shareholders' Fiduciary Responsibilities, 22 WAKE FOREST L. REV. 9, 11 (1987) (vehemence of courts' moralistic rhetoric explained by imprecision of fiduciary principles).

58. See Farnsworth, Good Faith Performance and Commercial Reasonableness Under the Uniform Commercial Code, 30 U. CHI, L. REV. 666, 678-79 (1963); Summers, "Good Faith" in General Contract Law and the Sales Provisions of the Uniform Commercial Code, 54 VA. L. REV. 195, $215-17$ (1968); Weinrib, The Fiduciary Obligation, 25 U. TORONTO L.J. 1, 1-3 (1975).

59. See infra notes 65-106, 136-60 and accompanying text. Professor Summers argues that the obligation to act in good faith can best be understood as an "excluder"-that is, as a concept, without a general meaning of its own, that takes on specific meaning in particular contexts by excluding various forms of bad faith. Summers, supra note 58, at 201 . 
Many contracts cases, along with the Restatement (Second) of Contracts, assert that every contract imposes on its parties an obligation of good faith and fair dealing in its performance and enforcement. ${ }^{60}$ Likewise, section 1-203 of the Uniform Commercial Code provides that, "Every contract or duty within this Act imposes an obligation of good faith in its performance or enforcement."61 In applying this obligation, the analysis focuses on the parties' relationship following their agreement, not prior to it. ${ }^{62}$ As illustrated below, ${ }^{63}$ beliavior that may be innocuous pre-agreement may become problematic post-agreement, owing to the constramts imposed by the obligation. In this respect, the contractual obligation to act in good faith is like fiduciary obligation, which similarly requires an analysis that focuses on the parties' positions after their relationship lias been established.64

1. A Limit on Rights Granted by the Agreement or by Law. Stated generally, the obligation to act in good faith limits a party's discretion to use powers or advantages that it has by virtue of an agreement or, in some instances, by virtue of law. In Pillois v. Billingsley, ${ }^{65}$ for example, the Second Circuit treated the good faith obligation as a constraint on a party's ability to exercise a right expressly granted by an agreement. In that case, the defendant employed the plaintiff as an agent to obtain long-term rights to a perfume trademark in the Uinited States; the parties' written agreement provided that the principal would pay the agent "such sum as you [the principal], im your sole judgment, may decide is reasonable."66 The agreement further provided: "You [the principal] have made no other commitment and have no other obligation to ine [the agent] of any kind whatsoever."67 Read literally, the written agreement seems to have given the principal unfettered discretion to inake any determination it chose about the agent's compensation. The court held that the agent was entitled to recover the reasonable value of the services he performed, because the agreement entitled the agent "to have the [princi-

60. See Restatement (SECOND) of Contracts $\S 205$ (1981). The first Restatement contained no such provision. Id. $\$ 205$ reporter's note.

61. U.C.C. $§ 1-203$ (1978). The separate, but equally pervasive, concept of good faith purchase is beyond the scope of this Article, as is the obligation to negotiate in good faith that is imposed in some contexts.

62. See id. § 1-203 official comment (concept applies to "performance or enforcement of every contract or duty within this Act").

63. See infra notes $92,146-47$ and accompanying text.

64. See Weinrib, supra, note 58, at 6 (fiduciary obligation looks to parties' relative positions following, not preceding, their agreement).

65. 179 F.2d 205 (2d Cir. 1950).

66. Id. at 207 .

67. Id. 
pal] in good faith determine the reasonable value of his services and to pay him that amount."68 In Pillois, the good faith obligation precluded the principal from inaking no determination of the value of the agent's services; it likewise precluded the primcipal from determining that the services liad value but failing to pay for them. ${ }^{69}$

Coininentators occasionally cliaracterize the obligation to act in good faith as one directed at "opportunistic" beliavior, or a party's use of discretion to recapture opportumities foregone upon entering into the contract. ${ }^{70}$ While this explanation works neatly in some cases, its ex-

68. Id. (emphasis added).

69. Pillois provides a useful contrast to cases involving claims for compensation for a defendant's use of a plaintiff's proposal for a new product or improved production technique. In Davis v. General Foods Corp., 21 F. Supp. 445 (S.D.N.Y. 1937), the plaintiff sent her recipe for a new food product to General Foods after receivimg a letter from General Foods that stated: "We shall be glad to examine your idea for a new food product, but only with the understanding that the use to be made of it by us, and the compensation, if any, to be paid therefor, are matters restimg solely in our discretion." Id. at 446. The court held that the defendant was under no obligation to compensate the plaintiff for its use of her recipe because the defendant's letter was too indefinite to constitute an offer for a contract. Further, the fact that the letter left any payment to the defendant's "discretion" defeated the plaintiffs claims based on an implied-in-fact contract or on restitution. Id. at 446-47. In Pillois, in contrast, the plaintiff performed services for the defendant after the parties agreed in writing that the plaintiff would act as the defendant's agent. Even read literally, the agreement in Pillois would not enable the defendant to argue that the parties intended no legal consequences to flow from the agreement or their relationship.

The facts in Davis more closely resemble those in Osborn v. Boeing Airplane Co., 309 F.2d 99 (9th Cir. 1962), in which an employer solicited suggestions from its employees, using a form that stated: "Suggestions are submitted with the understanding that the Company shall have the right to use all those which are adopted, and the decision of the Company shall be final and conclusive as to the person entitled to a cash award and the amount of such award." Id. at 100 (quoting the form). The court held that this language was not so clear that the trial court could hold as a matter of law that Boeing reserved absolute discretion to use a valuable idea without paying for it. The form, in the court's reading, was susceptible of an interpretation that Boeing had discretion only to determine whether to use a particular suggestion and which claimant was entitled to a reward for it and then "to determine in good faith the sum which would reflect the reasonable value of the idea." Id. at 103. The language in Davis, however, by expressly stating that General Foods would determine the compensation, "if any," to be paid, strongly hints, at a minimum, of the possibility that General Foods might determine to pay nothing.

70. See Burton, Breach of Contract and the Common Law Duty to Perform in Good Faith, 94 HARV. L. REv. 369, 373 (1980); cf. Jordan v. Duff \& Phelps, Inc., 815 F.2d 429, 438 (7th Cir. 1987) (implied term in every contract is that "neither party will try to take opportunistic advantage of the other"), cert. dismissed, $108 \mathrm{~S}$. Ct. 1067 (1988).

Developing a definition of "opportunistic" that suffices to explain the outcomes of the cases is difficult. In particular, it is hard to specify with precision even the general types of opportunities that a party may not attempt to recapture. Some cases subject an employer's decision to terminate an employee at will to a standard of good faith. See, e.g., Cleary v. American Airlines, Inc., $111 \mathrm{Cal}$. App. 3d 443, 456, 168 Cal. Rptr. 722,729 (1980) (long-term employee may not be terminated "without good cause"); Fortune v. National Cash Register Co., 373 Mass. 96, 104-05, 364 N.E.2d 1251, 1257 (1977) (jury could find bad faith where employer terminated salesman in order to avoid paying entire amount of commission due on goods already sold); Monge v. Beebe Rubber Co., 114 N.H. 130, 133, 316 A.2d 549, 551 (1974) (jury could find bad faith where employer terminated factory 
planatory power weakens in cases like Pillois, in which the defendant's use of discretion was apparently consistent with the express terms of the written agreement. ${ }^{71}$ And if the focus of this obligation were the defendant's attempt to recapture lost opportunities, cases holding that the defendant breached the obligation should structure the plaintiff's remedies around restitutionary norms to compel disgorgement of the benefit wrongfully - or "opportunistically" —obtained by the defendant at the plaintiff's expense. The cases, however, articulate no restitutionary primciple consistent with the criterion of "opportumistic" behavior as the basis for recovery.

The obligation to act in good faith inay also constrain a party's ability to use a power implicitly granted by law. Cases holding that an employer's right to terminate an employee at will is subject to a good faith obligation use that obligation to himit the employer's exercise of a power granted by the common law. ${ }^{72}$ Similarly, under the Uniform Commercial Code, the obligation of good faith apphies to proposals to modify a contract $^{73}$ and to demands for adequate assurance of counterperformance..$^{74}$ Of course, if the power at issue is itself heavily circumscribed by the positive law creating it, the party exercismg the power

worker who resisted foreman's sexual overtures, and factory personnel manager knew of foreman's pattern of sexual advances).

Suppose an employee at will is terminated to enable the employer to hire another employee capable of performing the same work with the same degree of competence but for less compensation. The employer's action fits within most people's definition of "opportunistic," but the termination may well pass muster under the "good faith" standard. The cases applying the good faith standard to terminations involve a variety of factual circumstances. The "good cause" formulation in Cleary is closest to the facts of the hypothetical, because it might be interpreted to mean that the employer must establish some deficiency in the employee's job performance in order to justify the termination. The appellate court's opinion in Cleary expressly notes, nonetheless, that in such litigation the employee has the burden of proving "some hidden motive" for the discharge. $111 \mathrm{Cal}$. App. $3 \mathrm{~d}$ at 453 n.5, 168 Cal. Rptr. at 728 n.5. The plaintiff in Cleary alleged that his union activities were the real reason for his discharge, and that in terminatiug him the employer failed to follow its own written procedures. The court's holding couples these allegations with the employee's longevity of service, stating that together they operate as "a form of estoppel." Id. at 456, 168 Cal. Rptr. at 729. Cleary concludes by placing on the plaintiff at trial "the burden of proving that he was terminated unjustly." Id. at 456, 168 Cal. Rptr. at 729 . Of course, being terminated "unjustly" potentially encompasses much more than termination because of an employer's "hidden motive."

71. Characterizing the obligation to act in good faith as exclusively a response to sequential performance in contracts does not explain Pillois. See R. POSNER, supra note 44, at 81-82. The agent in Pillois could, of course, have readily protected itself against the risk of eventual nonpayment by requiring payment in advance or by declining to give the principal express discretion to determine payment. Likewise, the fact of sequential performance is not especially helpful in explaining cases that impose a good faith constraint on an employer's power to terminate an employee at will. See infra note 72 and accompanying text.

72. See e.g., Cleary, 111 Cal. App. 3d at 448-49, 453, 168 Cal. Rptr. at 725, 727-28; Fortune, 373 Mass. at 102, 364 N.E.2d at 1256; Monge, 114 N.H. at 132-33, 316 A.2d at 551.

73. U.C.C. § 2-209 official comment 2 .

74. Id. $\S 2-609$ official comment 3 . 
inay serve an essentially ininisterial function, like a mortgagee exercising a power to sell property subject to a mortgage. ${ }^{75}$ The constraint of a good faith obligation-like that of fiduciary obligation-apphes only to situations in which a person may exercise discretion.

Additionally, when an agreement creates a relationship in which one party's decisions can severely limit the benefit that the other party will derive from the agreeinent or drastically increase the cost of performance, the obligation to act in good faith may constrain decisions that would otherwise be within the parties' independent discretion. ${ }^{76}$ The decision of the New York Court of Appeals in Kirke La Shelle Co. v. Paul Armstrong Co. typifies a group of cases in which the owner of a hiterary or theatrical property, having hicensed one party to exploit the property in a particular inediun, subsequently hicenses another party to exploit the property in another medium, to the detriment of the initial licensee. 77 The licensor in such cases is subject to an "inipled negative covenant" not to use the ungranted portion of its rights to the detriment of the earlier licensee. ${ }^{78}$ Indeed, the court in Kirke La Shelle characterized this restraint as steinming froin "the duty of utmost good faith" that arose

75. See G. OSBORNE, MORTGAGES 727-29, 732-33 (2d ed. 1970). In contrast, in a contract for the sale of goods, a buyer's right to resell rightfully rejected goods and a seller's right to resell goods after a buyer's wrongful rejection include relatively more discretion for the party exercising the power to sell. Like a creditor who may sell collateral after a debtor's default, the aggrieved buyer or seller may decide to conduct a private rather than a public sale. U.C.C. $\$ \S 2-603,2-706,9-504$. The decision to sell in all three instances is subject to a test of "commercial reasonable[ness]," e.g., id. \$9-504 official comment 1 , which meshes neatly with the Code's express definition of "good faith" for merchants in sales transactions: "honesty in fact and the observance of reasonable commercial standards of fair dealing in the trade," $i d . \$ 2-103(1)(b)$.

Furthermore, a mortgagec exercising a power to sell is understood to be using a power given to him for his own benefit. See G. OsBORNE, supra, at 733. In contrast, the constraint of good faith means that the power to sell goods under the U.C.C. cannot be characterized as one given to the seller for his exclusive benefit.

76. Of course, all bilateral contracts create in each party an expectation of receiving the other party's performance. These expectations frequently lead to substantial out-of-pocket expenditures by one or both parties. Either or both parties may, moreover, forego attractive alternative opportunities. One commentator discerns in the caselaw a developing principle that once a contractual relationship has been created, "a party has a duty to perform in a manner calculated, at least in part, to 'protect' the other party." Hillman, An Analysis of the Cessation of Contractual Relations, 68 CORNELL L. REv. 617, 658 (1983) (claracterizing relationships between contracting parties as "quasi-fiduciary").

77. 263 N.Y. 79, 85, 188 N.E. 163, 166 (1933); see also Manners v. Morosco, 252 U.S. 317,327 (1920); Harper Bros. v. Klaw, 232 F. 609, 613 (S.D.N.Y. 1916).

78. See Kirke La Shelle, 263 N.Y. at 84, 188 N.E. at 167.

The terms of the initial license can easily be structured to limit the scope of the implied negative covenant. See generally 3 M. Nimmer \& D. Nimmer, Nimmer on Copyright § 10.11[A] (1987) (express reservation of motion picture rights violates implied negative covenant; license that does not expressly provide for exclusivity does not preclude grantor from licensing competitors). The covenant is effectively vitiated if the initial license is nonexclusive, see Hart v. Cort, 83 Misc. 44, 46-47, 144 N.Y.S. 627, 628-29 (Sup. Ct. 1913) (nonexclusive license to produce play), or if the licensor 
from the "fiduciary relationship" established by the parties in their contract. 79

Perhaps the court was using the term "fiduciary" more metaphorically than analytically. If the licensor-licensee relationship in Kirke La Shelle created a fiduciary obligation, the consequences of that obligation diverge significantly from the consequences of other fiduciary obhigations. The hicensor remained free to act in its own self-imterest and, under the court's formulation, breached its obligation to the licensee only because the subsequent licensee actually injured the initial licensee.80 Likewise, the damages recovered by the hicensee in Kirke La Shelle are not consistent with fiduciary obhigation as conventionally understood. The licensee recovered lialf the licensor's proceeds from the subsequent license, a split-the-benefit approach hostile to the basic restitutionary principle that supposedly governs remedies for breaches of fiduciary obligation. ${ }^{81}$

expressly reserves rights in a medium not granted to the mitial licensee, see Macloon v. Vitagraph, 30 F.2d 634, 635-36 (2d Cir. 1929).

79. Kirke La Shelle, 263 N.Y. at 85, 188 N.E. at 166; cf. Cinerama Prods. Corp. v. Schwartz, 147 N.Y.S.2d 484 (Sup. Ct. 1956) (declining to impress equitable hen on motion picture that used song composed by defendant while he was under exclusive commitment to complete unusical score for plaintiff, but allowing plaintiff to recover $\$ 42,500$ paid to defendant under agreenent for defendant's exclusive engageinent).

80. A related body of caselaw addresses the meaning of a party's obligation to use its best efforts to pursue an activity beneficial to the other party. Express promises to use best efforts are typical in licensing and franchising agreements. In agreements for exclusive dealing in goods, U.C.C. § 2-306(2) provides that unless the parties expressly agree otherwise, the seller has an obligation to use best efforts in supplying the goods, and the buyer has an obligation to use best efforts to promote their sale. Courts have tolerated competition by the best-efforts promisor with the promisee unless the promisee demonstrates that the promisor has failed to consider the promisee's interests equally with its own. See Goetz \& Scott, Principles of Relational Contracts, 67 VA. L. REv. 1089, 1124 \& n. 77 (1981).

81. The split-the-benefit outcome in Kirke La Shelle contrasts sharply with Boardman v. Phipps, [1967] 2 App. Cas. 46, a leading English case dealing with the consequences of the breach of a more traditional fiduciary obligation. In Boardman, the defendants were a beneficiary of a trust that owned shares in a company, and a solicitor serving as an advisor to the trustees of that trust. The defendants were held liable to account to the trust for profits made in transactions with the company's shares, even though the effect of the transactions (which included a takeover bid for the company) benefited the trust financially. Even in cases like Boardman, where the defendants' actions were not kept secret from their advisees and had a dennonstrably positive impact on the value of trust property, if the fiduciary is liable to account, then that liability covers all profits realized through transactions offensive to the fiduciary's position. But the House of Lords held that the Boardman defendants' good faith entitled them to payment "on a hiberal scale" for their work and skill in obtaining the shares and resultant profits; this lolding mitigated somewhat the financial consequences of the litigation for the defendants. Id. at 104 (Colen, L.J.). A general problem in the law of restitution is separating the plaintiff's traceable interest im property or "profits" from the defendant's own contribution. See generally G. PALMER, supra note $16, \S 2.12$, at $161, \S 2.13$. 
2. Output and Requirements Contracts. Many cases interpret the significance of the good faitl constraint as it applies to parties with the power to determine quantity in output and requirements contracts. ${ }^{82}$ Under the Uniform Commercial Code, as under the common law, if an agreement gives a seller the right to determine, through its "output," the quantity of goods that the buyer is obliged to purchase, then an obhigation of good faith in performance expressly limits the seller's discretion to determine its own output. ${ }^{83}$ Likewise, if under the agreement the buyer has power to set quantity by reference to its own "requirements," a standard of good faith performance expressly controls that counterpart power. 84

As it happens, one of the cases that typically illustrates the power of fiduciary obligation in the corporate context also imvolves a requirements contract and thus furnishes a concrete situation in which to differentiate the fiduciary constraint from tlie obligation to act in good faith. In Globe Woolen Co. v. Utica Gas \& Electric Co., the plaintiff, a textile company, sued a utility company to compel specific performance of a requirements contract for electricity. ${ }^{85}$ At the time of the contract's formation, the two corporations shared a common director, Mr. Maynard, who was also the chief stockholder of the textile company. The requirements contract contained a pricing formula guaranteemg that the buyer would save money by using electricity instead of steam power, but the contract did not limit the conditions under which the mills were to be run. The utility's directors approved the contract at Maynard's beliest (voting, however, while he absented himself from the room), and on the basis of estimates of the mills' likely power needs that were prepared by a utility employee, whoin Maynard separately compensated for the service. ${ }^{86}$

Soon after the requirements contract went into effect, the textile company drastically changed the mix of products processed in its mills, which dramatically increased its power "requirements."87 The estimate presented to the utility's directors had not forecast such a change. The contract, by virtue of its pricing formula, soon became a losing one for the utility; by the time of the litigation, the utility owed the textile com-

82. See E. FARNSWORTH, supra note 31, § 7.17, at 528-29; Weistart, Requirements and Output Contracts: Quantity Variations Under the U.C.C., 1973 DuKE L.J. 599.

83. U.C.C. $\$ 2-306(1)$.

84. Id. . Additionally, the seller or buyer in such relationships cannot be required to tender or accept a quantity of goods "unreasonably disproportionate to any stated estimate" or, in the absence of such an estimate, to any normal or prior quantity, even if the quantity-determining party is acting in good faith. Id. $\$ 2-306(1)$ \& official comment 3 .

85. 224 N.Y. $483,485,121$ N.E. 378,378 (1918).

86. Id. at $486-88,121$ N.E. at $378-79$.

87. Id. at 488,121 N.E. at 379. 
pany $\$ 11,721.41$ for the privilege of supplying it with electricity for free. The court denied specific performance, emphasizing Maynard's failure to warn his fellow directors of the likelihood of significant changes in the textile company's business. ${ }^{88}$

But would the outcome in Globe Woolen have been different if the two corporations had not had a director in common? The alacrity with which the buyer increased its requireinents and the equally sudden shift in its product mix both appear inconsistent with a buyer's obligation to use good faith in inaking decisions that determine quantity. ${ }^{89}$ Additionally, the equitable nature of the specific performance remedy sought by the buyer in itself makes the plaintiff's apparent bad faith relevant. Thus, even if a requirements contract does not oblige the buyer to inform the seller of aspects of its business plan that could result in large future increases in its requirements, ${ }^{90}$ the buyer's power to determine quantity under such a contract is subject to the good faith constraint. And under the Uniform Commercial Code, even if the buyer's requirements increase in good faith, the buyer may not deinand any quantity "unreasonably disproportionate" to any stated estimate or, in the absence of an estimate, to its prior coinparable requireinents. ${ }^{91}$ On the facts of Globe Woolen, then, the fiduciary constraint on the corporations' common director seems to contribute little to the outcome.

In other situations, however, the fiduciary constraint would contribute much. That the two corporations in Globe Woolen shared a common director, likely to favor the buyer's interests, means that the parties' discretion $\mathrm{m}$ deahing with each other was limited prior to their formal agreement to enter into the requirements contract.92 Fiduciaries may transact with their beneficiaries ouly if they are candid about facts within their knowledge pertinent to the transaction. To the extent that the good faith obligation constrains a party's discretion in a requirements contract, it does so only once the contract is formed and is far from an absolute obligation to share information.

In addition, good faith obligation looks to how parties actually perform and use the powers created by their agreeinent, and not to their capacity to deal, as does the "candor" aspect of fiduciary obligation. ${ }^{93}$

88. Id. at $491-92,121$ N.E. at $380-81$.

89. See U.C.C. § 2-306 official comment 2 (contrasting "sudden expansion" with "normal expansion undertaken in good faith").

90. See Clark, supra note 10, at 71-72.

91. U.C.C. $\$ 2-306(1)$.

92. Though the contractual relationship would arise only upon conclusion of the formal agreeinent, the fiduciary relationship was estabhished when the director accepted the two positions. See supra note 64 and accompanying text.

93. See infra note 181. 
For example, a requirements buyer who secretly invests in a seller's competitor has not violated the good faith constraint; the investment would not justify the seller's rescission of the contract because it is not an abuse of the buyer's power to determine quantity. ${ }^{94}$ Likewise, a defendant's subjective motives are relevant to questions of good faith, but may well be irrelevant to a court's consideration of fiduciary obligation in many contexts. ${ }^{95}$

Most importantly, if a fiduciary obligation constrains a person's discretion in a particular matter, the obligation is breached if the person acts self-interestedly. Good faith obligation, on the other hand, permits actions that are self-interested; ${ }^{96}$ the key question is abuse, not benefit to the actor. In a relationship established by a requirements contract, the buyer's requirements may vary as a direct result of the buyer's profitinaximizing business decisions. ${ }^{97}$ The fundamental assumption that a fiduciary may not retain profits derived from transactions undertaken on behalf of the beneficiary, except with the beneficiary's consent, goes well beyond the obligation to act in good faith.

In addition, the presence of a fiduciary obhigation significantly affects the conduct of litigation by affecting the allocation of burdens of proof. If a suit challenges a transaction between a fiduciary and a beneficiary, the fiduciary has the burden of proving that it dealt candidly and fairly with the beneficiary. ${ }^{98}$ If the issue is, in contrast, merely whether a party has breached a contractual obligation, the party alleging the breach has the burdens of proof. ${ }^{99}$

Moreover, the remedies available to a beneficiary in litigation against a fiduciary differ from standard contract remedies. The beneficiary is entitled to restitution of any benefit realized by the fiduciary througl the breach, or alternatively may recover any loss suffered as a result of the breach. In order to fully capture these benefits, expansive remedies, such as the imposition of a constructive trust, may be necessary. ${ }^{100}$ Contract remedies, as explained above, ${ }^{101}$ are less exotic, and the

94. See U.C.C. § 2-306 official comment 2.

95. See Boardman v. Phipps, [1967] 2 App. Cas. 46, 104 (Cohen, L.J.) (irrelevance of fiduciary's good faith as defense to action for accounting of profits acquired by reason of fiduciary position).

96. See supra notes 83-84 and accompanying text.

97. See U.C.C. $\$ 2-306$ comment 2 ("Reasonable elasticity in the requirements is expressly envisaged by this section and good faith variations from prior requirements are permitted .... The essential test is whether the party is acting in good faith.").

98. W. Cary \& M. Eisenberg, Corporations 585 (5th ed. 1980).

99. See Restatement (SECOND) of Contracts $\$ 360$ comment b (1981) ("If the injured party has suffered loss [caused by the breach] but cannot sustain the burden of proving it, only nominal damages will be awarded.").

100. Weinrib, supra note 58, at 19. 
plaintiff typically receives only money dainages equal to the value of his lost expectation. Indeed, in many situations, establishing that a party failed to act in good faith merely excuses the other party's obligation to counterperform. ${ }^{102}$

Though these differences are far from trivial, one provocative similarity between the two types of obligation also exists. The obligation to perform in good faith is not susceptible to disclaimer through agreement. ${ }^{103}$ But the parties may control the extent of the obhigation through the type of relationship that they create in their agreement. For example, a provision in a requirements contract disclaiming the seller's right to limit the buyer's use of the quantity-setting power under a good faith criterion would be invalid; a fixed-quantity contract, on the other hand, by not conferring quantity-setting discretion on either party, does not imphicate this aspect of the good faith constraint.

Fiduciary obligation is, in most respects, susceptible of the same analysis. If the relationship, as the parties structure it, does not confer discretion on the "fiduciary," then his actions are not subject to the fiduciary constraint. Even a designated "trustee" may not be a fiduciary if he entirely lacks authority and thus has no discretionary power. ${ }^{104}$ And if the "trust" relationslip expressly does not require the trustee to administer the trust on behalf of the beneficiaries, one would view the parties' use of the term "trust" as an oxymoron. ${ }^{105}$ This basic point is crucial to understanding the connection between the parties' express agreement

101. See supra note 39 and accompanying text.

102. See E. FARNSWORTH, supra note $31, \S 8.15$, at $610-11$ ("A party whose performance is hindered or prevented by the other party in violation of the duty of good faith may not be limited to a claim for damages for the other party's breach. If the breach is material, the injured party can suspend his performance and, should the breach continue too long, he can terminate.").

103. See U.C.C. § 1-102(3).

104. See J. SHEPHERD, supra note 55, at $21 \mathrm{n} .1$ (shell corporation created to act as inactive trustee may not be under fiduciary obligation).

105. See Lehane, Fiduciaries in a Commercial Context, in Essays IN EQuiTy 95, 101 (P. Finn ed. 1985) (to say that trustee need not conduct trust's affairs on behalf of beneficiaries is "virtually a contradiction in terms").

Less extreme examples testing the definition of trusteeship arise in connection with indenture trustees under corporate debt agreements. The federal Trust Indenture Act of 1939 does not disqualify a financial institution that is a creditor of the issuer of debt securities from serving as an indenture trustee. The dual trustee-creditor role is inherently one of conflict, however, and one of palpable conflict if the issuer experiences financial reverses. See Campbell \& Zack, Put a Bullet in the Poor Beast. His Leg is Broken and His Use is Past. Conflict of Interest in the Dual Role of Lender and Corporate Indenture Trustee: A Proposal to End It in the Public Interest, 32 Bus. LAW. 1705, 1720-28 (1977). Prior to enactment of the Trust Indenture Act, which defines the minimum acceptable requirements of the indenture trustee's role, trust indenture language frequently limited the trustee's responsibilities to essentially ministerial ones. Furthermore, some courts limited the trustee's obligation to literal compliance with the indenture's express terms. See V. BRUDNEY \& M. Chirelstein, Corporate Finance 148-49 (3d ed. 1987). 
and any fiduciary or good faith obligations that may apply. The parties' express agreement, along with their conduct toward each other, defines their relationship, while the law defines the obhigations inherent in a particular type of relationship. ${ }^{106}$ To be sure, we would be profoundly skeptical of such agreements in some contexts-a ward's agreement that his guardian retain profits generated by the ward's property is an obvious example-but this qualification does not defeat the basic point.

\section{B. Vulnerable Parties and Problematic Transactions.}

In many relationships in which one party is bound by a fiduciary obligation, the other party's vulnerability to the fiduciary's abuse of power or influence conventionally justifies the imposition of fiduciary obligation. ${ }^{107}$ Much of contract law, in contrast, presupposes that "a contract is the result of the free bargaining of parties who are brought together by the play of the market and who meet each other on a footing of social and approximate econormc equality."108 The autonoiny and self-determination of the parties, not their vuhierability, are the key assumptions. Still, many aspects of contract law operate to protect vulnerable parties against the consequences of unwise or disadvantageous transactions, in some instances even if the party benefiting from a given transaction did not behave wrongfully in inducing assent to that transaction. The consequences of these protective or policing functions of contract law nonetheless differ significantly from the imposition of fiduciary obligation. This Article does not attempt a comprehensive treatment of all the protective aspects of contract law; it addresses only those aspects that best illuminate the distinctive characteristics of fiduciary obligation. The next subsections thus explore the protective character of rules dealing with contract formation and capacity to contract, as well as some of the doctrines that regulate overreaching and misbehavior in the bargaining process.

106. In the most general sense, of course, the same point can be made about contracts. Along these lines, the Uniform Commercial Code defines the parties" "agreement" as "the bargain of the parties in fact as found in their language or by implication from other circumstances including course of dealing or usage of trade or course of performance." U.C.C. § 1-201(3). The parties' "contract," in contrast, is "the total legal obligation which results from the parties' agreement as affected by this Act and any other applicable rules of law." Id. § 1-201(11). Of course, the parties' agreement and their contract are not identical to any written instrument expressing the agreement.

In the context of a constructive trust, however, legal obligations may be imposed in the absence of any contract or agreement. See infra note 144.

107. See Frankel, supra note 55, at 809-10.

108. Kessler, Contracts of Adhesion-Some Thoughts About Freedom of Contract, 43 CoLUM. L. REv. 629, 630 (1943). 
1. Contract Formation and the Protection of Vulnerable Parties. Not all agreements create legally enforceable obligations; rules that specify the conditions for contract formation, althougl general in their application, unquestionably operate to protect some vulnerable parties. For example, the classical rules of offer and acceptance, by requiring that an acceptance precisely mirror the terms of the offer to whicli it responds, ${ }^{109}$ delay contract formation and thereby create opportunities for reflection and exit from improvident commitments. By limiting the effectiveness of silence as a mode of acceptance for offers, ${ }^{110}$ these rules also protect the liapless or mattentive offeree agamst tlie officious offeror.

Similarly, an entirely gratuitous undertaking of an obligation is not enforceable because of the consideration requirement, whicl conditions the enforceability of an agreement on a promised exchange of value. ${ }^{111}$ Strong adherents of the view that contractual obligation is exclusively rooted in individual self-determination, not surprisingly, find the consideration requirement anomalous. ${ }^{112}$ The protective aspect of that requirement is itself a major liurdle to any theoretical attempt to reduce contract law to a statement of primciple like "the free arrangements of rational persons should be respected."113 Indeed, these rules of contract formation may be overprotective and may invite abuses, but their prophylactic aspects are undeniable.

Capacity doctrines in contract law liave a self-evidently protective function. They protect general categories of persons who lack the requisite capacity to contract-in individual instances, justifiably or notfrom obligations that they have undertaken. Thus, contracts entered into by infants or the mentally infirm, two categories of persons whose presumptive vulnerability is evident, are voidable by the infant ${ }^{114}$ or the mentally incompetent person. 115 The differences between tlie consequences of contractual incapacity and fiduciary obligation, as they protect quintessentially vulnerable parties, are, however, significant. Contracts entered into by infants are voidable by the infant but are otherwise enforceable on their terms; also, if an infant affirms a contract after reaching the age of inajority, a court does not evaluate the fairness or

109. See E. FARNSWORTH, supra note $31, \S 3.13$, at 138 .

110. See Restatement (SECOND) OF CONTRACTS $\S 69$ (1981).

111. E. FARNSWORTH, supra note 31, § 2.5.

112. See, e.g., C. Fried, Contract AS Promise 35 (1981).

113. Id.

114. E. FARNSwORTH, supra note $31, \S 4.4$.

115. Id. $\S \S 4.2,4.6$. 
wisdom of the contract's terms if either party subsequently breaches. ${ }^{116}$ In short, the protective function of the capacity requirement is confined to the infant's choice to affirm or disaffirm the contract; the law trusts the former infant's acuity and self-interest in determining which contracts to affirm and which to avoid.

In contrast, if the infant or mentally incompetent person has a guardian, the norms of fiduciary obligation and the applicable statutes pervasively regulate that relationship. For example, in all jurisdictions the guardian must obtain court approval to sell real estate belonging to the ward. ${ }^{117}$ Transactions between guardians and their wards are presumptively invalid and voidable by the ward. ${ }^{118}$ An infant ward's ability to disaffirm contracts entered into witl his guardian may reach contracts made even after the infant has attained the age of majority. In order to enforce sucl a contract, the guardian has tlie burden of showing that the challenged transaction "was understood, was fair and reasonable, and that no advantage was taken" by the guardian. ${ }^{119}$ The ward's dependence on the guardian, as the defining feature of their relationship, dictates a presumption of undue influence regarding subsequent transactions that is inapplicable to the former ward's transactions witl other persons.

In addition, the fiduciary duty of loyalty to a ward's interests obliges the guardian to account for any profits made througl use of the ward's property. Along these lines, in In re Estate of Swiecicki, the Supreme Court of Illinois held that a guardian bank was liable to account to its ward for the profits it realized by investing the ward's property in the bank's own savings accounts and certificates of deposit. 120 The bank's interest in these transactions, as a borrower and subsequent lender of the ward's funds, is in evident confiict witl the ward's imterest as a lender. A bank would obviously profit more by borrowing its ward's money at a lower rather than a higher rate of interest. Equally obviously, banks not in a fiduciary relationslip with a ward are free to profit from their transactions witli the ward.

116. Id. §4.4. Jurisdictions vary in the extent to which the minor who disaffirms a contract must make restitution for value received from the other party's performance of the contract. See id. $\S 4.5$.

117. See $1 \mathrm{H}$. Clark, The Law of Domestic Relations in the United States 565 (2d ed. 1987). In some states court approval is required for all transactions, including mortgages and rentals, involving any part of the ward's real or personal property. See, e.g., N.C. GEN. STAT. § 35A1301 (1987).

118. E.g., Ostic v. Mackmiller, 53 N.M. 319, 324, 207 P.2d 1008, 1010-11 (1949).

119. Williams v. Canary, 249 F. 344,346 (8th Cir. 1918).

120. 106 III. 2 d 111, 123, 477 N.E.2d 488, 493 (1985). The court was unpersuaded by the defendant's argument that only its trust department served as the ward's guardian, while any profit was made by its commercial department. The court held that the bank as a whole, and not just one department, owed the fiduciary duty. Id. at 122, 477 N.E.2d at 492. 
The guardian bank in Estate of Swiecicki paid interest "at the inarket rate,"121 but that fact does not justify its retention of the profits. The fiduciary's obligation to account does not depend on the beneficiary's ability to demonstrate injury from the self-dealing. The beneficiary's interest might, for example, be best served by a guardian institution that would not be distracted by self-interest in deciding whether diversifying the ward's investments would be the best strategy, but the ward does not have the burden of establishing that the guardian's actions deprived him of this advantage.

Thus, fiduciary obhgation is more intensely protective than contract law's capacity rules, but only of those relationships to which it applies. Indeed, the selectiveness with which fiduciary obhigation applies further distinguishes it from the general and indiscriminate applicability of the capacity rules, which occasionally confer "protection" on persons who do not need it and who may even be injured by their inability to enter into prospectively binding commitments. Mature seventeen-year-olds who want to start businesses are not well served by a rule inaking all their contracts voidable. ${ }^{122}$ It is much less likely that a ward would be injured by his guardian's prospective difficulties in purchasing the ward's property or retaining the profits generated through the guardian's use of it.

2. Restricting Tactics in the Bargaining Process. Contract law is also sensitive to some types of behavior in the bargaining process by which one party may prey upon or exploit the vulnerability of another party. Some types of behavior, such as intentional misrepresentation and physical duress, constitute wrongfnl acts that inay be separately actionable as torts. Other problematic behavior-like nonfraudulent misrepresentations, unconscionability, and economic duress-although less culpable, may nonetheless justify rescission. As the doctrines addressing such conduct have evolved, the key concern has become the perceived unfairness of the resulting transaction to the victini, ratlier than the culpability of the advantaged party. ${ }^{123}$

Once again, however, the legal consequences of fiduciary obligation differ. As apphied, the contract doctrines focus on whether the disadvantaged party suffered an actual injury. In contrast, as Estate of Swiecicki illustrates, fiduciary obligation is sensitive to any divergence of the parties' interests, even if it appears that the beneficiary has not, in fact, suf-

121. Id. at 134, 477 N.E.2d at 498 (Ryan, J., dissenting).

122. See E. FARNSWORTH, supra note $31, \S 4.3$, at 215.

123. Id. $\S 4.9$, at 234. 
fered a measurable injury. ${ }^{124}$

An additional point of comparison is the parties' ability to withhold information during the bargaining process. As noted above, ${ }^{125}$ a party's affirmative inisstateinents preceding an agreement may enable the opposite party to avoid the contract. The right to avoid is limited, however, by the requirement that the party seeking to avoid estabhsh that he relied on the statement at issue, that the reliance was reasonable, and that the statement concerned a inatter purportedly based on knowledge and did not merely express the speaker's opimion. ${ }^{126}$

If a fiduciary makes a misstateinent to his beneficiary, a court will assess the statement in light of the fiduciary's obhigations to be candid and to give priority to the beneficiary's interests. In particular, the fiduciary's obligation to be candid weakens the significance of two distinctions drawn by contract law, namely, the distinctions between statements of fact and statements of opinion and between affirmative misrepresentations and nondisclosures. Differentiating statements of fact from statements of opinion is less miportant if the speaker, as a fiduciary, has an obligation of candor: like the common director in Globe Woolen, the fiduciary inay often be obliged to share his opinion honestly with the beneficiary of the relationship. ${ }^{127}$ Further, the fiduciary may be hable to the beneficiary for losses that result from the beneficiary's rehance on the opinion. ${ }^{128}$ Contract law also differentiates imstances of "simple nondisclosure" from affirmative misstatements, and only recently, im narrowly delimited instances, has permitted "smiple nondisclosure" to justify avoiding a contract. ${ }^{129}$ For fiduciaries, who inust be candid, the distinction is irrelevant.

3. Complementary Insights from Fiduciary Analysis. Occasionally, the legal consequences of fiduciary obhigation coinplement rather than conflict with the results of contract analysis as applied to an identical instance of problematic behavior. The facts of a 1917 Kentucky Supreme Court case, McDevitt v. Stokes, ${ }^{130}$ suggest an especially vivid example. Contemporary contracts scholars treat $M c D e v i t t$ as an illustra-

124. See 106 Ill. $2 d$ at 119,477 N.E.2d at 491.

125. See supra notes $82-91$ and accompanying text (output and requirements contracts).

126. See E. FARNSWORTH, supra note $31, \S 4.14$.

127. See Globe Woolen Co. v. Utica Gas \& Elec. Co., 224 N.Y. 483, 489, 121 N.E. 378, 380 (1918) ("The trustee . . . cannot rid himself of the duty to warn and to denounce . . ..").

128. The liability of investment advisers and money managers to their clients for the negligent preparation or rendition of investment advice illustrates the application of this principle. See $2 \mathrm{~T}$. Frankel, The Regulation of Money Managers 645-59 (1978).

129. See E. FARNSwoRTH, supra note $31, \S 4.11$.

130. 174 Ky. 515, 192 S.W. 681 (1917). 
tion of an extreme application of the "prior duty" rule for modifications of agreements. ${ }^{131}$ In McDevitt, the owners of a horse named Grace hired the plaintiff, a jockey, to drive Grace in a trotting race. Subsequent to the jockey's engagement, but prior to the race, the defendant, who owned horses related to Grace, promised to pay the jockey an additional $\$ 1000$ if Grace won the race. Grace (and the jockey) won, but the defendant reneged. The court held that the defendant's promise was unenforceable because when the defendant made it the jockey, as an agent of Grace's owner, "was already morally and legally bound to perform the service required of him."132

Contract law polices agreements to modify prior contracts in an effort to himit a party's ability to exploit another party's need to receive an already-agreed-to performance. The common law im some jurisdictions and section 2-209 of the Uniform Commercial Code determine whether assent to a proposed inodification has been improperly extorted, that is, whetler the proposal has been made in good faitli. The prior duty rule, in contrast, apphes without regard to whether the proponent of the modification has acted in good faitli; $M c D$ evitt thus seems close to a preposterous apphication of the rule, because the jockey owed his prior duty to Grace's owner, not to the defendant.

The complementary insights afforded by the primciples of fiduciary obligation stem from the fact that the jockey in McDevitt was surely an agent of Grace's owners: they engaged him, subject to their control, to act on their behalf in driving Grace in a particular race. True, the jockey-horse owner relationship might not be the first that comes to mind as a quintessential agent-principal relationship, but the relationship satisfies all elements of any conventional definition of agency. ${ }^{133}$ An agent is bound by a fiduciary obligation to his principal, which encompasses a duty to account to the principal for any value received from third parties in connection with the agent's services on behalf of the principal, unless the principal consents to the agent's retention of the value received. ${ }^{134}$ On the McDevitt facts, unless Grace's owners consented to the jockey's

131. See E. FARNSWORTH, supra note $31, \S 4.21$, at 273 ; $c f$. RESTATEMENT (SECOND) OF CONTRACTS $\S 73$ (1981) (performance of legal duty owed to a promisor that is neither doubtful nor the subject of honest dispute is not consideration).

132. McDevitt, $174 \mathrm{Ky}$. at 517, 192 S.W. at 681.

133. See RESTATEMENT (SECOND) OF AGENCY $§ 1(1)$ (1958) (“Agency is the fiduciary relation which results from the manifestation of consent by one person to another that the other shall act on his behalf and subject to his control, and consent by the other so to act."). See generally J. HUMPHREYS, RACING LAW 283-99 (1963) (discussing nature of employment relationships between horse owner and jockey).

134. See RESTATEMENT (SECOND) OF AGENCY $\S 388$ (unless otherwise agreed, agent who profits in transactions on behalf of principal is under duty to give profit to primcipal). 
retention of the payment, the jockey had an obligation to account to them for his secret profit. The agent's fiduciary obligation to his principal, however, does not address the enforceability of the third party's promise to make the payment; fiduciary obligation prescribes only that if the agent secretly receives such a payment, he must account for it to his principal. ${ }^{135}$

McDevitt also neatly illustrates the rationale for the "secret profits" rule. If the jockey is free to receive and retam payments from third parties without the consent of Grace's owners-payments that are nonetheless contingent on Grace's victory-his mcentives to win may lead him to employ tactics inconsistent with the interests of Grace's owners. They presumably want Grace to survive the race in addition to winning it! This central preoccupation of fiduciary obligation-minimizing potential or incipient conflicts in parties' interests-is not a concern of contract law.

\section{GeNeral JUSTIFICATIONS FOR FIDUCIARY Obligation}

Legal commentators have inade several attempts to develop general justifications for fiduciary obligation; that is, to describe in a coinprehensive and analytic fashion those aspects of relationships that justify imposition of fiduciary constraints. This part explores the strengths and limitations of four distinct attempts to capture that ever-elusive prey, fiduciary obligation, in a general legal theory. Although inuch can be learned from such attempts to state general justifications for the fiduciary constraint, the explanatory power of each atteinpt is limited.

In part, fiduciary obligation eludes theoretical capture because it arises in diverse types of relationships. Coinınon characteristics of sucl relationships include the fiduciary's commitinent to exercise discretion in a fashion that affects the interests of the beneficiary and the fiduciary's obligation to exercise that discretion on the beneficiary's behalf. Paradigms of sucl1 relationships include agent-principal, director-corporation, guardian-ward, lawyer-client, partner-fellow partner, and trustee-trust beneficiary relationships. The scope of the fiduciary's obligation, as well as the obligation's precise formulation, necessarily varies witl the context of the relationship. As the law has developed, trustees are under

135. A principal may have an action in restitution against a third party who agrees to pay a secret commission to an agent in connection with a transaction between the principal and the third party, whether the commission is paid or not. Compare Donemar, Inc. v. Molloy, 252 N.Y. 360, 169 N.E. 610 (1930) and Kinzbach Tool Co. v. Corbett-Wallace Corp., 138 Tex. 565, 160 S.W.2d 509 (1942) (third party liable to principal for amount of secret commission promised to agent) with RESTATEMENT OF RESTITUTION $\S 138(2)$ (1937) (third party who colludes with fiduciary in committing breach of duty and thereby receives benefit is under duty to make restitution to beneficiary). 
more stringent restrictions in their dealings with trust property than are corporate directors in their personal transactions with the corporation. ${ }^{136}$ As noted above, ${ }^{137}$ that a particular relationship fits within one of these conventional categories does not end the analysis, for the parties may have defined the characteristics of the relationship such that they foreclose the applicability of the fiduciary constraint.

The theoretical challenge has thus been to develop an account of fiduciary obligation that is more than merely descriptive and is suffciently analytic to permit its predictable application to a variety of diverse relationships and factual circumstances. This task is indeed of considerable practical import. Many courts are obviously willing to consider applying fiduciary obligation in situations beyond the conventional categories, mcluding, im recent years, commercial franchises, ${ }^{138}$ distributorship relationships, ${ }^{139}$ a bank's relationship with its borrowers ${ }^{140}$ and its depositors, ${ }^{141}$ and the relationship between holders of executive and nonexecutive interests in oil and gas estates. ${ }^{142}$ But, just as obviously, the mere existence of such a relationship does not mean that the parties to it always owe each other obligations of a fiduciary character. The question becomes whether one can articulate any general theory that justifies the imposition of fiduciary obligation, depending on the particular facts, across such a diverse group of relationships. The answer appears to be that ouly an mstrumental view of fiduciary obligation can address such a diversity of contexts. That is, viewed exclusively from an internal perspective, one limited to the logic of the concept itself, fiduciary obligation is inevitably tied to the particular context in which it arises. A general account of fiduciary obligation thus requires at least modest use of an external perspective to explaim the recurrence of common (but variable) principles in such different contexts. According to this view, courts impose fiduciary constraints whenever one person's discretion ought to be

136. See RESTATEMENT (SECOND) OF TRUSTS $\S 2$ comment $b$ (1959) ("The duties of a trustee are more intensive than the duties of some other fiduciaries."); R. CLARK, CORPORATE LAW $\$ 5.1$ (1986) (discussing the relaxation of restrictions on corporate directors).

137. See supra notes $103-06$ and accompanying text.

138. See Arnott v. American Oil Co., 609 F.2d 873 (8th Cir. 1979), cert. denied, 446 U.S. 918 (1980).

139. See Hospital Prods., Ltd. v. United States Surgical Corp., 55 A.L.R. 417 (Austl. 1984).

140. See Barrett v. Bank of America, 183 Cal. App. 3d 1362, 1369, 229 Cal. Rptr. 16, 20-21 (1986) (borrower perceived relationship with banker as "very close" and relied on banker's financial advice); see also Klein v. First Edina Nat'l Bank, 293 Minn. 418, 422, 196 N.W.2d 619, 623 (1972) (duty may arise in "special circumstances" where bank knows or has reason to know customer is placirtg trust in bank and relying on bank to counsel and inform him).

141. See Commercial Cotton Co. v. United Cal. Bank, 163 Cal. App. 3d 511, 516, 209 Cal. Rptr. 551, 554 (1985).

142. See Manges v. Guerra, 673 S.W.2d 180, 183-84 (Tex. 1984). 
controlled because of characteristics of that person's relationship with another. So much varies in the application of fiduciary principles in particular contexts that the conception of fiduciary obligation itself is unable to justify its applicability, as a general matter and irrespective of context. This view, however, does not deny that the concept of fiduciary obligation has content, or that the content is cogent and intelligible; any general theory of fiduciary obligation that ignored this content would lack integrity and persuasiveness.

\section{A. Voluntary Assumption Theories.}

Soine commentators stress the importance of the fiduciary's voluntary assumption of a position that requires him to further the interests of another. Along these lines, in 1949 Professor Austin Scott wrote: "Who is a fiduciary? A fiduciary is a person who undertakes to act in the interest of another person. It is immaterial whether the undertaking is in the forin of a contract. It is immaterial that the undertaking is gratuitous." 143 Imposition of the fiduciary obligation is in this view justified because the fiduciary himself "undertakes" to put himself in a position that imparts such an obligation. This view is unquestionably true in many relationships in which fiduciary obligations apply, including trusts, guardianships, and agency relationships.

But exceptions too significant to dismiss undercut the appeal of Scott's forinulation as a general justification. In some relationships, determining the precise nature of the parties' "undertaking" is a difficult task. And in some situations, Scott's formulation does not work at all. In what sense, for exainple, has a constructive trustee "undertaken" to act in the interests of the beneficiaries of the constructive trust? Typically the trust beneficiaries are the plaintiffs in litigation in which a court has imposed a constructive trust as a remedy. Only an overly attenuated conception of the trustee's "undertaking" could nake sense in this context. ${ }^{144}$

143. Scott, supra note 56, at 540. A subsequent writer characterized Scott's conception of fiduciary obligation as essentially contractual, despite the disclaimer quoted above. J. SHEPHERD, supra note 55, at 65. Inasmuch as Scott's discussion does not deal with issues like intent, which would seem to underlie any contractual conception of the basis of the duty, it is preferable to give the "undertaking" language a less technical reading.

144. Cf. Stoljar, Unjust Enrichment and Unjust Sacrifice, 50 MoD. L. REv. 603, 610 (1987) (characterizing constructive trust as example of situation in which person has fiduciary obligation thrust upon him). A contemporary example of the imposition of a constructive trust in the corporate context is Heckmann v. Ahmanson, $168 \mathrm{Cal}$. App. 3d 119, $214 \mathrm{Cal}$. Rptr. 177 (1985). In Heckmann the trial court, through a preliminary injunction, effectively imposed a constructive trust on the profit inade by a group of shareholders when the corporation repurchased their stock. The sellers had acquired their shares as part of a takeover bid for the issuer; in the course of the takeover contest, these shareholders brought a derivative action against the issuer's directors, challenging 
Similarly, corporate law in the United States treats majority or controlling shareholders in corporations, at least in the exercise of some of their powers, as fiduciaries of minority shareholders. ${ }^{145}$ Scott's formulation applies to such a relationship awkwardly, at best. When does the majority shareholder's undertaking to act on behalf of the minority occur-when the majority position is initially assembled, or when the majority exercises its powers?

Scott's formulation is also difficult to apply to relationships, like partnerships, that ultimately may be defined by a formal written agreement among the parties, but that, prior to the agreement, impose fiduciary obligations on the parties. Under the Uniform Partnership Act, each partner is accountable to the partnership for profits that he derives "from any transaction connected with the formation, conduct or liquidation of the partnership or from any use by him of its property." 146 Scott's formulation implicitly suggests that at an identifiable moment, fiduciary obligation is "undertaken," but the relationship among prospective partners may evolve less neatly and more fluidly. And suppose the future partners never reach final accord on the precise terms of their agreement. A search for the parties' dispositive "undertaking" of fiduciary obligation will only waylay analysis of the parties' relationship. Surely the appropriate inquiry is broader and encompasses whether the relationship was characterized by mutual trust and confidence, or whether it failed to progress beyond mere arm's-length negotiation. ${ }^{147}$

their opposition to the takeover bid. The share repurchase eliminated the plaintiffs' standing to prosecute the claims on behalf of the corporation's remaining shareholders. The court of appeals held that, in bringing the derivative action, the shareholders assumed a fiduciary position that they could not properly abandon for purely private benefit. Id. at $128-29,214$ Cal. Rptr, at 183-83. Thus, in the appellate court's view, the trial court appropriately treated the profits realized by the erstwhile representative plaintiffs as subject to a constructive trust.

145. See R. ClARK, supra note 136 , $\S 11.4$, at $488-90$, $\S 12.3 .5$, at 525 .

146. Unif. Partnership ACT $\S 21(1)$ (1969); see J. Crane \& A. Bromberg, LAW of PartNERSHIP 394 (1968).

147. See United Dominions Corp. v. Brian Proprietary, 60 A.L.R. 741, 747 (Austl. 1985) (relationship will "ordinarily" be fiduciary if intending partners have reached informal agreement to become partners and have taken steps to establish or implement partnership relationship).

In the United States, the Uniform Partnership Act defines partnership as "an association of two or more persons to carry on as co-owners a business for profit." UNIF. PARTNERshIP ACT § 6(1). The "association" requirement, according to the official comment, "implies the acting togetler of two or more persons ... to carry on a business." Id. official comment 1. If the business is not carried on after the parties reacl agreement and after they make partnership contributions, the parties are still partners. See id. Thus, under this defimition, persons negotiating a definitive partnership agreement who act together short of carrying on an ongoing business would be partners even if their formal agreement is never finalized. 


\section{B. "Entrusting" Theories.}

In contrast, some commentators stress the "entrusting" element in many relationships to which the fiduciary constraint applies. A trustee, for example, holds and manages property solely on behalf of beneficiaries of a trust; the trust property is thus "entrusted" to its holder subject to the fiduciary constraint. ${ }^{148}$ The entrusting conception works best as applied to relationships in which the fiduciary's role is that of a propertyholder, with the trust serving as a powerful prototype. ${ }^{149}$ In other types of relationships in which a party is subject to fiduciary constraints, specifying precisely what has been entrusted is difficult. Especially difficult to rationalize under this theory is the imposition of the fiduciary restraint upon relationships in which the fiduciary's role is to advise the beneficiary. What exactly has been "entrusted" to a lawyer by a client, apart from the client's confidence in the lawyer?150

The Jordan case, which involved a corporation's repurchase of an employee-shareholder's stock, ${ }^{151}$ itself defies satisfactory analysis under this conception of fiduciary obligation. Which of the corporation's powers are "entrusted" to it subject to the encumbrance of fiduciary obligation? Only those powers relating to transactions directly between itself and its own shareholders? Or all powers that may affect shareholders' interests? Suppose the corporation, through its directors, adopts a dividend policy unfavorable to the econoimic interests of an identifiable cadre of shareholders. Is this use of the corporation's power to make dividend decisions a breach of its fiduciary obligation to all shareholders? Would the same analysis apply if the corporation's directors adopted a business plan with the same disparate impact on identifiable shareholder interests?

The "entrusting" conception of fiduciary obligation is also unpersuasive as applied to cases in which the fiduciary's use of power yields a benefit that the beneficiary would not have been legally entitled, for other reasons, to obtain directly for itself. Several cases hold employees and other agents liable to account to their employers or principals for an illegal bribe taken from a third person. ${ }^{152}$ Surely the principal did not "entrust" to the agent the power to extract bribes from third parties! If the subject of the fiduciary encumbrance is defined more broadly, perhaps as

148. See J. SHEPHERD, supra note 55, at 96 (proposing theory of transfer of encumbered power).

149. Id. at 22-23.

150. Cf. Model Rules of Professional Conduct Rule 1.7 (1983) (precluding lawyer from representing client if representation adversely affected or limited by responsibilities to another client).

151. Jordan v. Duff \& Phelps, Inc., 815 F.2d 429 (7th Cir. 1987), cert. dismissed, 108 S. Ct. 1067 (1988).

152. E.g., Jersey City v. Hague, 18 N.J. 584, 597, 115 A.2d 8, 16 (1955); Reading v. AttorneyGeneral, 1951 App. Cas. 507. 
the power to deal with third parties on the principal's behalf, the facts that the power was used for an illegal end, and thus that the principal could not itself directly use the power to the same end, make it hard to explain why the proceeds of the transaction belong to the principal.

\section{Descriptive Theories.}

Other general approaches lend themselves Iess readily to analytic use and instead only describe traits that relationships may have if the fiduciary constraimt applies to them. The first, most fully expounded by Gareth Jones, advocates use of the principle of unjust enrichment to aid inquiry into whether the fiduciary has breached his duty and, in some situations, what relief should be available to the complaining beneficiary. ${ }^{153}$ Unjust enrichment is undoubtedly a useful concept in many situations that raise perplexing questions of fiduciary obligation. For one thing, it helps explain the outcome in the bribe cases described above, in which the fiduciary cannot defend against the plaimtiff-principal's action by arguing that no benefit was taken because the bribe in many respects did not "belong" to the principal. ${ }^{154}$ Under this line of imquiry, the fact that the agent would be unjustly enriched if he could retain the bribe is dispositive. But the principle of unjust enrichment cannot explain as a general matter why some people are under the fiduciary constraint and others are not, and it inevitably requires a case-by-case examination of particular facts to determine whether the obligation apphes. The unjust enrichment principle, moreover, caunot explain why some fiduciaries may not retain profits realized through their positions even though they acted honestly in obtaining them. ${ }^{155}$

153. Jones, Unjust Enrichment and the Fiduciary's Duty of Loyalty, 84 LAW Q. REV. 472, 47475 (1968).

154. See id. at $476-77$.

155. See, e.g., Boardman v. Phipps, [1967] 2 App. Cas. 46, 104 (Cohen, L.J.). In contrast, in some jurisdictions, corporate directors may pursue "corporate opportunities" with impunity if they first offer the opportunity in question to the corporation and disinterested directors or shareholders, following appropriate disclosure by the directors, reject the opportunity. See Klinicki v. Lundgren, 298 Or. 662, 681-82, 695 P.2d 906, 920 (1985). The House of Lords in Boardman emphasized the trust beneficiaries' lack of consent to the defendants' pursuit of the opportunity and the fact that knowledge of the opportunity came to the defendants through their advisory relationship to the trust. Additionally, had the trustees required advice on whether to pursue the opportunity for the trust, they would have turned to their solicitor, Boardman, for advice. Boardman's purchases of shares for himself thus created, in the Lords' view, a possible confict between his personal interest and his duty.

The emphasis given these points in Boardman differs from the focus of corporate opportunity cases in the United States, which do not treat a director's personal interest in her corporation's rejection of a given opportunity as impermissibly creating a conflict with the director's duty to advise fellow directors, so long as the decision to reject the opportunity is made by disinterested directors. The "interested" director's need to recuse herself from participating in that decision deprives her 
Finally, some commentators emphasize characteristics of the relationships between fiduciaries and their beneficiaries that may, in some situations, invite abuse by fiduciaries. A beneficiary in significant respects depends upon and is vulnerable to the fiduciary. The power held by the fiduciary that enables hin to act to benefit the beneficiary also enables him to indulge his own interest and to mjure the beneficiary. ${ }^{156}$ One major contribution of this emphasis is that it helps to explain the strongly prophylactic character of fiduciary rules, which often seem structured to deter the fiduciary from undertaking particular types of transactions, whatever their merits may in retrospect turn out to be. But a general approach to fiduciary obligation needs to justify the presence of the fiduciary constraint in relationships between parties who are apparently able, at least prior to the relationslin, to protect their own interests. A generalized emphasis on "dependency" might also suggest that courts would be more inclined to impose fiduciary constraints in situations in which the fiduciary's behavior has actually harmed the beneficiary. The analogy to aspects of contract law, like the unconscionability and duress doctrines, which examine whether one party has actually exploited the other party's vulnerability, would be clear. Instead, such litigation typically focuses upon the benefit realized by the fiduciary.

Moreover, the law of fiduciary obligation is inapphicable to some situations in which one party is evidently vulnerable to abuse by another. One long-standing example is the relationship between a guarantor and a principal debtor for whose obligation the guarantor is secondarily hable. A principal debtor is under no general obligation to refrain from transactions that increase his risk of default and tlius the likeliliood that the guarantor will be obliged to satisfy the debt. Many of these transactions will also reduce the principal debtor's ability to satisfy the guarantor's subsequent claim for reimbursement. ${ }^{157}$ If the principal debtor indulges in a fraudulent conveyance, that is, a transfer of its assets, without fair consideration, that renders it insolvent, the guarantor can have the fraudulent conveyance set aside. ${ }^{158}$ But many transactions may increase the guarator's risk and still fall short of the fraudulent conveyance standard.

fellow directors, and the corporation, of the benefit of her advice. Based on Boardman, one might argue that the director, by accepting and retaining that office, thereby comes under a duty not to create obstacles to her ability to participate in decisions to be made by directors. See generally Austin, Fiduciary Accountability for Business Opportunities, in EQUITY AND COMMERCIAL RELATIONSHIPS 141 (P. Finn. ed. 1987) (discussing formulations of U.S. corporate opportunity doctrine in relation to developments in Australian and English law).

156. See Frankel, supra note 55 , at $800,810$.

157. Cf. RESTATEMENT OF SECURITY $§ 112$ (1941) (surety's right to exoneration by principal debtor).

158. See id. $\S 113$ (surety can have fraudulent conveyance set aside if surety would have a right of exoneration against principal debtor, were principal's obligation due). 
Guarantors, in short, seem no less vulnerable to injury inflicted by their principal debtors than principals are to abuse by their agents.

One could justifiably conclude that the law of fiduciary obligation is im significant respects atomistic. ${ }^{159}$ Common core principles may justify the outcomes reached by courts in types or patterns of relationships, but they lose force as applied to other types of relationships. Or, as Professor Finn has described the state of the law, "each duty itself defines the type of relationslnp to which it applies-each defines who is a fiduciary for its purposes . . . eacli duty exacts its own standard of acceptable conduct from the fiduciary to whom it applies." 160 Described instrumentally, the fiduciary obligation is a device that enables the law to respond to a range of situations in which, for a variety of reasons, one person's discretion ought to be controlled because of characteristics of that person's relationship with another. This instrumental description is the only general assertion about fiduciary obligation that can be sustained.

\section{FiduCIARY IsSUES IN CORPORATE LAW}

Defining the nature and scope of fiduciary obligation in the corporate context is a daunting task. This part of the Article tackles two somewhat narrower issues: First, what is the significance of some courts' assumption that a corporation owes a fiduciary obligation to its own shareholders? Second, in what respects is the notion of "contracting out" of fiduciary obligation an intelligible one in the corporate context?

Two basic points require initial clarification. It is helpful to distim. guish between the fiduciary obligation as it applies to parties within corporations and other duties that may be owed to a corporation that are not distinctively fiduciary in character. Corporate directors, for example, who surely occupy a fiduciary office, also owe the corporation a duty of care in fulfilling their office. That duty, however, is not distinctively fiduciary; inany persons, by virtue of the law or their own contractual undertakings, owe duties of care to other persons with whom they have nonfiduciary relationships. For example, motorists owe duties of care to pedestrians and to fellow motorists but are not, by virtue of these relationships, under any fiduciary constraint in their pursuit of self-interest!

159. See P. FinN, Fiduciary Obligations 4 (1977); see also Sealy, supra note 4, at 73 (term "fiduciary" not definitive of single class of relationships to which fixed set of rules and principles applies); Sealy, supra note 11 (discussing diverse rules applicable to various categories of fiduciaries).

160. P. FINN, supra note 159 , at 4 . Viewed from this perspective, the law of fiduciary obligation, protean in nature, closely resembles the contractual obligation to act in good faith. Both are susceptible of principled application, and both are coherent, but neither lends itself to concise statement as a neat analytic rule. See supra notes 65-106 and accompanying text. 
Likewise, an institutional fact lending considerable importance to litigation over issues of fiduciary obligation in the United States is the relative absence of clear, statutory, propliylactic rules regulating the use of powers by corporate directors and controlling sliareliolders. The particular power involved in Jordan-tlie corporation's power to repurchase its own shares-is a good example. In the United States, corporation statutes subject a corporation's repurcliase of its own shares to financial tests, in many instances the same tests applicable to dividend distributions. ${ }^{161}$ In otlier respects, however, statutory corporate law does not regulate those transactions. Uses of the power to repurcliase sliares have attracted litigation that lias tested the propriety of those decisions on a case-by-case basis. ${ }^{162}$ As it happens, many other countries subject the power to repurchase sliares to extensive statutory regulation ${ }^{163}$ or forbid sucl repurchases altogether. ${ }^{164}$ In this respect, litigation testing particular repurcliase decisions against fiduciary norms replaces general prospective regulation of the use of the power. ${ }^{165}$

\section{A. The Corporation as a Fiduciary.}

Some courts have stated that the corporation itself owes a fiduciary duty to its shareliolders. ${ }^{166}$ The Jordan inajority, for example, explicitly assumes that a corporation, in exercising tlie power to repurcliase shares, must act consistently with a fiduciary obligation owed to its own shareloolders. ${ }^{167}$ It is odd-or at least curious - to suppose that the corporation owes a fiduciary obligation to its own sliareliolders. Analysis reveals the hopelesly muddled consequences of such an assertion.

161. Massachusetts, alone among the states, has no statutory regulation of distributions, including share repurchases and dividends. However, any distribution that renders a corporation insolvent is illegal. See MasS. ANN. LAws ch. 156B, $\$ 61$ (Law. Co-op. 1979). For a detailed discussion of the statutory regulation of distributions through share repurchases, see MODEL BUSINESS CORP. ACT ANN. $\$ 6.40$, at $490-91$ (Supp. 1988) (statutory comparison).

162. See, e.g., Unocal Corp. v. Mesa Petroleum Co., 493 A.2d 946, 958-59 (Del. 1985) (directors acted in good faith, after reasonable investigation, in buying back shares); Cheff v. Mathes, 199 A.2d 548, 556 (Del. 1964) (directors made reasonable decision after direct investigation and professional advicc); Donahuc v. Rodd Electrotype Co., 367 Mass. 578, 603, 328 N.E.2d 505, 521 (1975) (director of close corporation did not act in utmost good faith and loyalty).

163. See Companies Act, 1985, \$\$ 162-169.

164. See Companies Code, 1981, § 129(1)(b), (5) (Austl.).

165. See generally DeMott, Comparative Dimensions of Takeover Regulation, in KNIGHTS, RaIDERS, AND TARgetS: The IMpact of The Hostile Takeover 398 (J. Coffee, L. Lowenstein \& S. Rose-Ackerman eds. 1988).

166. See, e.g., Kohler v. Kohler Co., 319 F.2d 634, 638 (7th Cir. 1963); Dolgow v. Anderson, 43 F.R.D. 472, 498-99 (E.D.N.Y. 1968).

167. See Jordan v. Duff \& Phelps, Inc., 815 F.2d 429, 435 (7th Cir. 1987), cert. dismissed, $108 \mathrm{~S}$. Ct. 1067 (1988), 
Conventionally, one assumes that the corporation itself is owed fiduciary obligations by many persons, including its directors, officers, and controlling shareholders. If the justification for imposing the fiduciary constraint in a particular relationship is to prevent or rectify self-interested uses of power by those subject to the constraint, the concept of fiduciary obligation implicitly presupposes that persons bound by the obligation are capable of possessing a self-interest that may diverge from the interests of the beneficiaries of the obligation. This concept is not readily applicable to a corporation, the interests of which are generally treated as identical to those of its shareholders as a group. ${ }^{168}$ True, particular shareholders' interests may diverge from those of other shareholders, or directors may use their powers inconsistently with the shareholders' imterests, but the notion that in theory a corporation's "own" interests could diverge from those of its shareholders is difficult to fathom. Indeed, corporation statutes generally permit a corporation to have as few as one shareholder, which makes the prospect of conflict even more unlikely. ${ }^{169}$

Moreover, the consequences of a rule that a corporation owes a fiduciary obligation to its own shareholders are startling. First, fiduciary obhigation, as conventionally understood, invests nondelegable discretion in the party bound by the obligation; ${ }^{170}$ corporations, as artificial persons, can act only through their agents. Even institutional fiduciaries such as banks and trust companies, which obviously act througlı natural persons, can act through employees under the institution's direct control. Corporate law, however, ascribes ultimate managerial responsibility to a corporation's directors, ${ }^{171}$ who are neither employees nor agents, ${ }^{172}$ but who possess intrimsically discretionary responsibility. A pervasive principle in corporate law is that directors are not hable for untoward consequences

168. See, e.g., R. CLARK, supra note 136, § 1.2, at 17-19; cf. Bratton, The Economics and Jurisprudence of Convertible Bonds, 1984 WIS. L. REV. 667, 730 (fiduciary duty to corporation distinguished from duty to individual stockholders). Interestingly, even comınentators who advocate expanding the scope of fiduciary obligation to encompass holders of debt securities discuss the obligation as one owed not by the corporation itself, but by the corporation's directors. See McDaniel, Bondholders and Stockholders, 13 J. CoRP. L. 205, 268-73 (1988).

169. The Revised Model Business Corporation Act, for instance, does not require that a corporation have any mininum nuinber of authorized or issued shares or holders of shares. $C f$. REVISED MODEL BUSINESS CORP. ACT $\$ 6.01$ (a) (1984) (corporation's articles of incorporation must prescribe classes of shares and number of shares for each class that the corporation is authorized to issue).

170. See P. FinN, supra note 159 , at 20 .

171. See, e.g., Del. CODE ANN. tit. 8, § 141(a) (1987); Revised MODEL Business CoRP. ACT $\S 8.01(b)$. In both statutes, the directors' responsibility can be modified by contrary provisions in the corporation's articles or certificate of incorporation.

172. See Restatement (SECOND) of AGENCY $\S 14 C$ (1958). Nor is the board of directors as a body an agent of the corporation. Id. $\S 14 \mathrm{C}$ coinment a. 
of decisions made in a good faith exercise of business judgment. ${ }^{173}$ In some states, statutes expressly permit directors, in making specified types of decisions, to consider the interests of persons and entities other than shareholders. ${ }^{174}$ These legal rules are not reconcilable with the proposition that the corporation itself owes fiduciary obligations to its shareholders. ${ }^{175}$

Second, in many cases, operating a business requires that the business undertake commitments and obhigations to creditors. These obligations inay require the payment of funds to creditors that might otherwise be distributed as profits to the business's owners. Some shareholders are likely to perceive commitments that the corporation makes to particular creditors as inconsistent with their economic self-interest as shareholders. Is this type of conflict proscribed by the corporation's fiduciary obligation to its shareholders?

Third, if the corporation owes a fiduciary obligation to each shareholder individually, does the majoritarian norm for shareholder decisionmaking apply to transactions that would otherwise breach the corporation's fiduciary obligation? Or is the assent of each individual shareholder necessary? ${ }^{176}$

Fourth, and most technically, if we suppose the corporation's interests to be potentially at odds with those of its shareholders, thus rationalizing the imposition of the fiduciary constraint on the corporation, could a shareholder ever sue derivatively on the corporation's behalf, alleging injury to the corporation? That is, how could a shareholder ever bring a representative action on behalf of an entity whose interests conflicted with his? 177

Perhaps Jordan's assertion that a corporation owes a fiduciary obligation to its own shareholders inerely reflects the judges' efforts to justify

173. See R. CLARK, supra note $136, \S 3.4$.

174. For example, under the Missouri statute, directors evaluating an acquisition proposal "may consider ... [s]ocial, legal and economic effects on employees, suppliers, customers and others having similar relationships with the corporation, and the commumities in which the corporation conducts its businesses." Mo. AnN. STat. § 351.347 (Vernon Supp. 1988); see also Minn. STat. AnN. $\S 302 \mathrm{~A} .251(5)$ (West Supp. 1988) (directors can consider interests of employees, customers, suppliers, creditors, and the economy, as well as commumity and social considerations); OHo REV. CODE ANN. § 1701.59(E) (Anderson Supp. 1987) (same).

175. See J. SHEPHERD, supra note 55, at 351-52 (director has fiduciary responsibility to shareholders).

176. See infra note 193 and accompauying text; see also supra note 155 (shareholder rejection of corporate opportunity).

177. The early authorizations for such actions in U.S. caselaw clearly distimguished derivative actions brought by shareholders on behalf of corporations from actions involving "real contests" or "controvers[ies]" between a plaimtiff shareholder and a corporation. See Hawes v. Oakland, 104 U.S. $450,453-54$ (1881). 
their decision to impose to a duty to disclose material information to any shareholder from whom a corporation repurchases shares. Analysis at this point is complicated by the applicability of federal securities law to transactions involving the purchase or sale of shares. 178 The basic antifraud and antimanipulation provision in the Securities Exchange Act of 1934, section 10(b), prohibits the use, in connection with the purchase or sale of securities, of any "manipulative or deceptive device or contrivance," as defined by rules promulgated by the Securities and Exchange Commission. ${ }^{179}$ Under the U.S. Supreme Court's recent interpretations of this section, a party's failure to disclose information to another party to a transaction is "deceptive" if it violates a duty to disclose owed to the other party. ${ }^{180}$ Inevitably, the Court's interpretation requires reference to bodies of law, other than section 10(b) itself, that create duties to disclose. The content of this aspect of federal securities regulation is thus parasitic on other law, often mcluding state-law principles of fiduciary obligation. ${ }^{181}$

178. In Jordan, the plaintiff alleged violations of section 10(b) of the Securities Exchange Act of 1934, as well as breaches of fiduciary duty and common law fraud. Jordan v. Duff \& Phelps, Inc., [1986-87 Transfer Binder] Fed. Sec. L. Rep. (CCH) I 92,724 (N.D. Ill. 1986), rev'd, 815 F.2d 429 (7th Cir. 1987), cert. dismissed, 108 S. Ct. 1067 (1988).

179. Securities Exchange Act of 1934, § 10(b), 15 U.S.C. $\$ 78 j(b)$ (1982).

180. See Dirks v. SEC, 463 U.S. 646, 654-55 (1983).

181. See generally L. Loss, FundameNTALS OF SECURITY REgUlation 726-38 (2d ed. 1988) (analyzing Rule 10b-5 caselaw). Nonetheless, in some respects it may be misleading to equate the duties to disclose imposed by federal securities regulation with those defined by courts interpreting the fiduciary constraint in a corporate context. Numerous provisions in the federal securities statutes and the SEC's rules require the disclosure of "all material facts." Within the Securities Exchange Act itself, the "material fact" language appears in sections 14(e) and 18(a). 15 U.S.C. $\S \S 78 \mathrm{n}(\mathrm{e}), 78 \mathrm{r}(\mathrm{a})$ (1982). The SEC has frequently used this terminology in rules defining prohibited conduct. See, e.g., Rule 10b-5(b), 17 C.F.R. $\S 240.10 b-5(b)$ (1988) (purchase or sale of security); Rule 13e-3(b)(1)(ii), 17 C.F.R. $\$ 240.13 \mathrm{e}-3$ (b)(1)(ii) (going-private transactions by issuers and affiliates); Rule 14a-9(a), 17 C.F.R. \& 240.14a-9(a) (proxy solicitation); cf. Rule 14e-3(d)(1), 17 C.F.R. $\$ 240.14(\mathrm{e})(3)(\mathrm{d})(1)$ (prohibition on certain communications of "material, non-public information" conceruing tender offers).

In contrast, as the Delaware Supreme Court and Chancery Court have articulated it, the fiduciary's obligation in the corporate context is one of "complete candor." See Weinberger v. UOP, Inc., 457 A.2d 701, 710-11 (Del. 1983); Lynch v. Vickers Energy Corp., 383 A.2d 278, 281 (Del. 1977). The Delaware Supreme Court has occasionally used the "material facts" standard to assess whether a party has complied with its obligation of complete candor. E.g., Rosenblatt v. Getty Oil Co., 493 A.2d 929, 944-45 (Del. 1985). But cf. Booth, The Emerging Conflict Between Federal Securities Law and State Corporation Law, 12 J. CoRP. L. 73, 98-99 (1986) (emphasizing significance of Delaware standard of rescissory damages). As applied to some types of information, an obligation of "complete candor" may require more extensive disclosure than the materiality standard requires. Complete candor suggests a sharing of all information taken into account or, at the least, all information relied upon by the fiduciary in making its decision to pursue a particular transaction. The material fact standard, in contrast, focuses exclusively on the decisionmaking process of the reasonable shareholder and on the types of information that, hypothetically, such a shareholder would consider significant. See, e.g., TSC Indus. v. Northway, Inc., 426 U.S. 438, 449 (1976) ("An omitted fact is material if there is a substantial likelihood that a reasonable shareholder would consider it important 
If the corporation itself is not bound by a fiduciary obligation to its shareholders, should the outcome be different when a corporation repurchases its own shares? That is, is the conceptually muddled ascription of fiduciary obligation to the corporation necessary to the plaintiff's success? The corporation's directors surely owe a fiduciary obligation to the corporation, and, in the United States, are often assumed to owe such an obligation directly to the corporation's shareholders as well. ${ }^{182}$ If directors cause the corporation to repurchase shares without disclosing pertinent information to the selling shareholders, the nonselling shareholders (the corporation) benefit from the director's breach of duty ${ }^{183}$ and are presumably accountable for the benefit they receive. ${ }^{184}$

In cases like Jordan, one would not be surprised if the directors themselves were nonselling shareholders, with a personal pecumary interest in the transaction. The directors in sucl1 a situation do not breach their obligations by purchasing shares for their own personal accounts, but they use their power in a fashion inconsistent witl tle interests of the selling shareholders. Indeed, prior cases permit individual shareholders to sue directly when the directors misuse their powers in causing the corporation to repurchase the shares. ${ }^{185}$ That an individual action is permitted, and the claim is not treated as one that must be asserted derivatively on the corporation's behalf, is consistent with treating the director's duty as one owed directly to the shareholders, even though the corporation itself purchases the shares. If the directors do not own shares themselves, and thus lack a personal pecuniary interest in the transaction, they breach a fiduciary obligation owed directly to the corporation's shareholders if they benefit nonselling shareholders by failing to deal candidly with the sellers. ${ }^{186}$

Should the outcome be different if the jurisdiction permits directors to purchase stock for themselves from the corporation's present shareholders without disclosing relevant nonpublic information known to the

in deciding how to vote."). Additionally, the uniform use of the materiality standard in the securities regulatory scheme inevitably raises the question whether a general or a transaction-specific threshold of relevance is being used. The standard of complete candor, in contrast, is certainly a situation-specific standard, as its origins in Equity make clear. See supra notes 7-10 and accompanying text.

182. See H. Henn \& J. Alexander, Laws of Corporations 627 (3d ed. 1983).

183. See Brudney, Insiders, Outsiders, and Informational Advantages Under the Federal Securities Laws, 93 HARV. L. REV. 322, 347 \& n.79 (1979); Gabaldon, supra note 18, at 1261.

184. See G. PALmer, supra note $16, \S 2.20$, at 221 . Even a person who innocently benefits from another's wrongful act is obliged to make restitution, unless he has given value for the benefit. Id.

185. See, e.g., Donahue v. Rodd Electrotype Co., 367 Mass. 578, 328 N.E.2d 505 (1975).

186. See Brudney, supra note 183 , at 347. 
directors but not the selling shareholders? ${ }^{187}$ Such a jurisdiction is likely to distinguish between a director's purchases in his individual capacity and his official use of power to cause the corporation to repurchase shares. ${ }^{188}$ If the director benefits personally through the corporation's purchase of shares, and the director knows price-relevant information not shared with the selling shareholders, the director acquires this benefit in breach of his fiduciary obligation. The selling shareholder inay rescind the transaction or recover money damages equal to the difference between the shares' value and their sale price. ${ }^{189}$ In the end, it is difficult to identify the analytic contribution of giving the corporation a fiduciary obligation to its own shareholders-but analysis of fiduciary concepts, rather than metaphorical use of fiduciary terminology, indicates this difficulty.

\section{B. "Contracting Out."}

Evaluating the concept of "contracting out" of fiduciary obligation requires a similar analysis. The general notion (or metaphor) of "contracting out" may einbrace various types of provisions and actions, including charter provisions that purport to vary fiduciary norms, and agreements among individual shareholders that include language exphcitly or imphicitly waiving the parties' rights to remedies otherwise available to them, such as appraisal rights and the right to petition for involuntary dissolution of the corporation. The following discussion will focus on issues raised by charter provisions.

187. Compare Dirks v. SEC, 463 U.S. 646,653 (1983) (director in possession of nonpublic information must disclose it or refrain from trading) with Hooker v. Midland Steel Co., 215 Ill. 444, 450 51, 74 N.E. 445, 447 (1905) (permitting director, in absence of "actual fraud," to purchase stock from shareholder without disclosing information that the director may have concerning stock's value) and Walsh v. Goulden, 130 Mich. 531, 539-40, 90 N.W. 406, 410 (1902) (same). Later Illinois cases modify the Hooker rule, following precedents from other states. See Agatucci v. Corradi, 327 Ill. App. 153, 157-58, 63 N.E.2d 630, 632 (1945) (officers purchasing shares must disclose special circumstances affecting stock's value that are known to them and not ascertainable from corporate books) (citing Strong v. Repide, 213 U.S. 419 (1909); Goodwin v. Agassiz, 283 Mass. 358, 186 N.E. 659 (1933); Gammon v. Dain, 238 Mich. 30, 212 N.W. 957 (1927); Buckley v. Buckley, 230 Mich. 504, 202 N.W. 955 (1925)). State law remains directly applicable, because the general antifraud provision in the Securities Exchange Act, despite its breadth, applies only to transactions in securities listed on national securities exchanges or, for nonlisted securities, transactions making use of an instrumentality of interstate commerce or the mails. State law is indirectly applicable as well, because the Court interprets section $10(\mathrm{~b})$ to require disclosure only when a party has a duty to disclose. Cf. Dirks, 463 U.S. at 654-55 (no general duty to disclose before trading on material nonpublic information); supra notes 178-81 and accompanying text.

188. See Northern Trust Co. v. Essaness Theatres Corp., 348 Ill. App. 134, 143-44, 108 N.E.2d 493, 497-98 (1952).

189. See Agatucci, 327 Ill. App. at 156, 158, 63 N.E.2d at 631-32. The court in Jordan, interestingly, did not cite the Illinois caselaw. 
What significance should a court ascribe to provisions in a corporation's charter that alter the constraints otherwise applicable to a fiduciary's dealings with the corporation? Prior cases considering the impact of exculpatory clauses have declined to give effect either to provisions shifting the burden of proof that the law would otherwise impose, ${ }^{190}$ or to provisions attempting to shield officers and directors from hability arising from self-dealing transactions. ${ }^{191}$ The judicial response to these provisions suggests, once again, thiat the "contract" metaphor used in Jordan is seriously misplaced. To the extent that recent ainendments to corporation statutes permit charter provisions reducing or eliminating directors' liability, the statutory amendments preclude limiting or excluding liability when the director derives an improper personal benefit. 192

Characterizing such provisions as the product of a "contracting" process does not advance analysis. For example, if sliareliolders approve such charter language, do they breach a contract with the corporation's directors if they eliminate the provision througl a subsequent amendment? Occasionally, corporate law does effectively treat some aspects of corporate bylaws or charters as "contractual" by requiring the consent of all parties benefited by certam provisions im order to cliange them. Some cases take this view of bylaw or charter provisions that embody restrictions on share transferability, even if the corporation's bylaws or charter pernit amendment of the provisions by vote of a mere majority of the shares. ${ }^{193}$ But the rhetoric (or metaphor) of "contracting out" does not tell us how extensively the law of contracts applies to these provisions. Nor does it tell us which of contract law's various aspects might be applicable. Moreover, when shareholders approve an exculpatory provision, it is unlikely that they foresee with any particularity the variety of circumstances and transactions to which the provision miglit apply. ${ }^{194} \mathrm{Giv}$ ing literal effect to a broad exculpatory provision, then, seems inconsistent with the situation-specificity of fiduciary obhgation itself. After all, one of fiduciary obligation's essential characteristics is its very lack of an abstract essence that can be defined invariantly or independently of particular contexts. ${ }^{195}$

190. See Pappas v. Moss, 393 F.2d 865, 867-68 (3d Cir. 1968).

191. See Irwin v. West End Dev. Co., 342 F. Supp. 687, 701 (D. Colo. 1972) ("Exculpatory provisions of corporate articles create no license to steal.").

192. See, e.g., Del. CODE ANN. tit. 8, § 102(b)(7)(iv) (Supp. 1986).

193. See Bechtold v. Coleman Realty Co., 367 Pa. 208, 213, 79 A.2d 661, $663-64$ (1951); Cowles v. Cowles Realty Co., 201 A.D. 460, 466, 194 N.Y.S. 546, 551 (1922).

194. See Ali, Principles of Corporate Governance: ANalysis and RecommendaTIONS $\S 5.09$ comment d(2) (Tent. Draft No. 7, 1987).

195. See supra notes $159-60$ and accompanying text. 
The caselaw determining the effect of exculpatory provisions is more fully developed in the law of trusts. A provision in a trust instrument cannot reheve a trustee of hability for any profit derived from a breach of trust, and cannot reheve the trustee of hability for breaches of trust committed intentionally, in bad faith, or with reckless imdifference to the interests of the beneficiary. ${ }^{196}$ An exculpatory provision is also meffective to the extent that its insertion in a trust imstrument results from the trustee's abuse of a confidential or fiduciary relationship with the settlor. 197

Courts' reluctance to be more indulgent of exculpatory provisions in trust agreeinents is significant in the corporate context as well. Arguably, the "contract" metaphor is more pertinent to a trust instrument, because in the creation of a trust, true bargaining between the settlor and the trustee is likely to occur. ${ }^{198}$ Except in closely held corporations, the "bargain" that a corporation's charter represents between its shareholders and directors is more abstract: ouly rarely would shareholders know its content and even more rarely would they negotiate with the directors about that content. ${ }^{199}$ In any event, although the "contract" metaphor seems more plausible as applied to relationships created by a trust agreement, trustees are severely limited in their ability to "contract out" of hability for breaches of trust. In the corporate setting, where the analogy between a trust instrument and a charter is often weak, an indulgent reading of a broad exculpatory clause has even less to recoinmend it.

\section{CONCLUSION}

Fiduciary obligation has a number of characteristics that classify it among the law's most exotic species. Its origin in Equity and its continuing tie to Equity's legacy make it unusually context-bound as a legal obligation. The considerable variety of relationships in which parties are bound by fiduciary obligation further complicates the analysis. Determining whether fiduciary obligation applies in a particular context and what requirements inhere in the inposition of fiduciary obligation demands recognition of this situation-specificity.

Although, as this Article demonstrates, careful analysis can resolve many questions about fiduciary obligation, the difficulty of that undertaking should not be underestimated. Shortcuts in legal reasoning through metaphoric and unanalytic appeals to contract law serve only to

196. See Restatement (SECOND) OF TRUSTS § 222(2) (1959).

197. See id. § 222(3).

198. See ALI, supra note 194, § 7.17 reporter's note 2 (Tent. Draft No. 8, 1988).

199. See id. 
muddle the analysis. Only a move from metaphor to analysis can resolve these recurrent questions of fiduciary obligation. 